\title{
Rising From the Ashes: \\ How Brands and Categories Can Overcome Product-Harm Crises
}

\author{
Kathleen Cleeren
}

Harald J. van Heerde

Marnik G. Dekimpe*

September 10, 2012

\begin{abstract}
* Kathleen Cleeren is Assistant Professor, Maastricht University, PO Box 616, 6200 MD Maas tricht, The Netherlands (Tel.: +31-43388 3624; Fax: +31-43 388 4918; E-mail: k.cleeren@maastrichtuniversity.nl). Harald van Heerde is Professor of Marketing at the University of Waikato, Private Bag 3105, 3240 Hamilton, New Zealand (Tel.: +64 - 7838 4089; Fax: +64 - 7838 4352; E-mail: heerde @ waikato.ac.nz ). Marnik G. Dekimpe is Research Professor of Marketing, Tilburg University, PO Box 90153, 5000 LE Tilburg, The Netherlands, and Professor of Marketing, Catholic University Leuven (Tel.: +31 - 13466 3423; Fax: +31 - 13 466 8354; E-mail: m.g.dekimpe@uvt.nl).
\end{abstract}

The authors are indebted to AiMark for data access. They also thank participants at the 2010 Copenhagen Emac Conference, at the 2010 Cologne Marketing Science Conference, at the 2011 Jaipur Marketing Dynamics Conference, and at the marketing seminar series at Singapore Management University for several useful comments. The second and third authors thank the New Zealand Royal Society Marsden Fund (UOW1004) for research support. Part of the paper was written while the third author was the Tommy Goh Visiting Professor in Entrepreneurship and Business at Singapore Management University. 


\title{
Rising From the Ashes: \\ How Brands and Categories Can Overcome Product-Harm Crises
}

\begin{abstract}
Product-harm crises are omnipresent in today's marketplace. Such crises may cause major revenue and market-share losses, lead to costly product recalls, and destroy a carefully nurtured brand equity. Moreover, some of these effects may spill over to non-affected competitors in the category when they are perceived guilty by association. The extant literature lacks generalizable knowledge on the effectiveness of different marketing adjustments managers often consider to mitigate the consequences of such events. To fill this gap, the authors analyze, using large household-scanner panels, sixty FMCG product crises that happened in the UK and the Netherlands, and which resulted in the full recall of an entire variety. The authors assess the effects of post-crisis advertising and price adjustments on the change in consumers' brand share and category purchases. In addition, the authors consider to what extent the effects are moderated by two key crisis characteristics: the extent of negative publicity surrounding the event, and whether or not blame had to be acknowledged publicly by the affected brand. Based on the empirical findings, the authors provide context-specific managerial recommendations on how to overcome a product-harm crisis.
\end{abstract}

$\underline{\text { Keywords: }}$ product-harm crisis, product recall, defective product, purchase behavior, negative publicity, blame. 
Product-harm crises are omnipresent in today's marketplace. Recent notable examples include Toyota's worldwide recall of more than seven million cars because of technical problems, the melamine contamination in several Chinese baby-formula brands, and Mattel's toy recalls because of their lead paint hazard. These crises may cause major revenue and market-share losses, and destroy a carefully-nurtured brand equity (Chen, Ganesan, and Liu 2009; Thirumalai and Sinha 2011). Moreover, a product-harm crisis may not only be devastating for the affected brand, it may affect the entire category when other brands are perceived guilty by association (Roehm and Tybout 2006). Because of the increasing complexity of products, more stringent product-safety legislation, and more demanding customers, product-harm crises are expected to occur ever more frequently (Dawar and Pillutla 2000).

When faced with a product-harm crisis, managers want to make informed decisions on their marketing variables to attenuate the negative impact of the crisis. In the summer of 2006, several Cadbury chocolate products had to be withdrawn from the UK market because of a serious salmonella contamination. While the brand's relative price remained at a comparable level, management dramatically increased its advertising support, leading to $30 \%$ more share of voice in the post-crisis year. When Princess, a canned-pilchards brand, had to be removed from the shelves because of a packaging fault, it also increased its advertising support substantially. However, it also increased its relative price by more than $25 \%$, perhaps in an attempt to recoup lost revenues. In contrast, when a plastic contamination led to the recall of candy manufacturer Basset's milky-baby lollies, Basset followed an entirely different strategy of decreasing both its advertising share of voice and its relative price. While there is a growing research interest in the 
impact of product-harm crises, little empirical evidence is available on the relative effectiveness of these different recovery strategies (Liu et al. 2012).

There is an extensive literature (using mostly experiments and/or surveys) that focuses on how consumers deal with the negative publicity typically surrounding product-harm crises (see e.g., Ahluwahlia, Burnkrant, and Unnava 2000; Griffin, Babin, and Attaway 1991) and/or how consumers are influenced by blame attributions (e.g., Dutta and Pullig 2011; Klein and Dawar 2004). Research on the impact of these factors is important given that not all companies choose to take the blame in a crisis context, while the amount of negative publicity surrounding a crisis can be very different. Although both Cadbury and Basset acknowledged that they were to blame, the amount of negative publicity surrounding the crises was very different. While the Cadbury crisis was covered in all major UK newspapers, the recall of Basset's milky-baby candy was only picked up in one. Even though previous studies have discussed the impact of both crisis characteristics (blame and publicity) on post-crisis consumer attitudes and/or behavior, they remain agnostic to what extent managers should adjust their marketing variables depending on these crisis characteristics.

Another set of studies has used empirical purchase and sales data to assess how the effectiveness of advertising and/or price changes due to a crisis (see e.g., Cleeren, Dekimpe, and Helsen 2008; Van Heerde, Dekimpe, and Helsen 2007; Zhao, Zhao, and Helsen 2011). Van Heerde et al. (2007), for example, document that the salmonella contamination of an Australian peanut butter brand reduced its advertising effectiveness (from a significant pre-crisis level to a non-significant post-crisis level), but not its price elasticity. Studying the same case, Cleeren et al. (2008) confirm that post-crisis advertising was ineffective to induce renewed trial of the 
affected brand, while Zhao et al. (2011) report, using a consumer-learning model on the very same case again, a significant drop in advertising elasticity of the affected brand along with a slightly decreased post-crisis price sensitivity. All three studies therefore cast doubt on the usefulness of an increased advertising support following the crisis, while they report mixed results on the effectiveness of post-crisis price changes.

Still, given that all three studies looked at the same product-harm crisis, little is known on whether the reported post-crisis marketing effectiveness remains idiosyncratic to that specific crisis $^{1}$, whether this generalizes to other settings, or whether crisis characteristics such as the extent of negative publicity and/or the acknowledgement of blame moderate the ultimate effectiveness of different marketing adjustments. If a product recall causes extensive media coverage (see e.g., the Cadbury crisis described above), does this call for more advertising once the product returns to the shelves, or is it better to stay out of the public eye? Similarly, if the company had to take the blame for the recall, does it reduce a firm's ability to raise prices to recoup some of the lost revenues?

In this study, we take a contingency-based view, and allow the effectiveness of marketing changes - that often take place in the wake of a product-harm crisis - to depend on both the extent of the negative publicity (which may vary widely from one crisis to another) and whether or not the firm/brand had to acknowledge the crisis was its fault. Apart from its high managerial relevance, developing hypotheses on, and empirically testing the role of, moderators is also important from an academic point of view, as it advances theory development by identifying boundary conditions for existing theory. Whetten $(1989, \mathrm{p} .492)$, for example, argues that "contextual factors set the boundaries of generalizability, and as such constitute the range of the 
theory." For more arguments in support of the role of moderators in theory development, see, e.g., MacInnis (2011, p.144) and Yadav (2010, p.7). Moreover, in contrast to prior research that treated marketing adjustments as exogenous, we explicitly account for the endogenous nature of the changes managers make once confronted with a major product-recall situation.

Finally, unlike prior research that focused almost exclusively on the performance implications for the affected brand(s), we also consider the implications on the category as a whole. Because of the increasing prevalence of product-harm crises, even the most cautious brand may be confronted with a doom scenario when consumers perceive the problem hitting one of its, perhaps less cautious, competitors as a potential industry-wide problem. Again, the effectiveness of post-crisis price and advertising may depend on the type of crisis facing the category.

This study contributes new insights along two dimensions: it develops a contingency framew ork that (i) bridges research on crisis characteristics and the post-crisis effectiveness of advertising and price, and (ii) studies their main and interactions effects on, respectively, brand share and category purchases. Moreover, given that we empirically test this framework on a unique data set covering sixty full recalls in the FMCG sector, we considerably add to the empirical knowledge base on the phenomenon.

The rest of the paper is organized as follows. We first present our conceptual framework. Next, we discuss our modeling approach, describe the operationalization of the variables, and report the results. The final section summarizes the findings and offers managerial implications. 


\section{CONCEPTUAL FRAMEWORK}

Product-harm crises can seriously hurt a firm's performance (e.g., Chen et al. 2009). Apart from the obvious impact on the affected brand, the entire category may be affected when the inadequacy of the production process is perceived as an industry-wide problem (De Alessi and Staaf 1994). Therefore, we focus on two key performance metrics, i.e., the affected brands' share and the level of category purchases, both at the individual-household level. We study crisis characteristics and their moderating impact on the effectiveness of marketing adjustments. We also include a number of control variables. Figure 1 summarizes our conceptual framework. In what follows, we discuss the rationale of the variables in our framework, and develop hypotheses on the interactions between crisis characteristics (negative publicity and blame) and the marketing variables (price and advertising). ${ }^{2}$

\section{Crisis Characteristics}

Negative publicity. Negative publicity is the extent to which the media report on the product-harm crisis. Negative news is weighted more heavily in product evaluations than positive news, because it is perceived more diagnostic and surprising (Herr, Kardes, and Kim 1991). Moreover, negative news is typically broadcast by news media and not by the brand itself, and audiences tend to perceive media as more trustworthy (Wang 2006). Negative publicity has been shown to hurt firm performance in a variety of contexts such as critical movie reviews (Basuroy, Chatterjee, and Ravid 2003) and negative online book reviews (Chevalier and Mayzlin 2006). Also in the context of product-harm crises, the potentially detrimental effect of bad publicity has been discussed (see, e.g., Lei, Dawar, and Lemmink 2008). 
However, recent research suggests that negative publicity need not always be bad, in line with the age-old phrase "Any news is good news". Berger, Sorensen, and Rasmussen (2010) find that publicity may increase awareness and accessibility, regardless of the valence of the message. Their reasoning behind this result is that people may forget over time the valence of the information, while the awareness remains, and the product (category) may become more top of mind. Therefore, in the case of negative publicity surrounding product-harm crises, merely mentioning a brand or category may increase its awareness and accessibility in the consumers' mind. Even though prior research has often discussed this phenomenon in the context of book or movie reviews, a similar dissociation of awareness and valence of information has been reported in Skurnik et al. (2005) in the context of false claims for different non-cultural products (e.g., aspirin and corn chips), and in Moore and Hutchinson (1985) for negative advertising.

Blame. Blame accounts for whether or not the company acknowledges responsibility for the product-harm crisis. When a product fails, consumers are likely to search for attributions of blame (Lei, Dawar, and Gürhan-Canli 2012). Blame attributions can have serious consequences for a company, since they lead to anger toward the company and to negative word-of-mouth (Folkes 1984; 1988). Since this causes a decrease in future purchase intentions (Folkes 1988), we expect that acknowledging blame will affect brand share negatively. With regard to category purchases, one could argue that consumers will perceive the problem as less diagnostic for the category when one specific company takes the blame for the crisis. This decreases the likelihood of spillover to non-affected competitors (Roehm and Tybout 2006). Not only does this reduce the uncertainty as to the locus of fault, but implicitly also suggests that the others are not to blame. Still, the fact that an industry member was to blame may well be more serious than if a third 
(outside) party was the culprit, as it may indicate that the industry's (self) regulation was insufficient to prevent the problem from occurring.

\section{The effectiveness of marketing adjustments}

Managers often increase advertising support or decrease the price in the wake of a product-harm crisis in an attempt to regain lost consumers (Cleeren et al. 2008). Competitors in the same category may also boost advertising expenditures or lower their prices to benefit from the misfortune of the affected brand(s). Alternatively, firms may well consider raising their prices in the wake of the crisis. Indeed, managers have been shown to very often increase price $(p)$ when demand $(q)$ is unexpectedly low (Marn, Roegner, and Zawada 2003), in an attempt to avoid revenue ( $p \times q)$ losses (see also Rotemberg and Saloner 1986). We test whether the effectiveness of post-crisis advertising and price adjustments is moderated by the crisis characteristics, i.e., the amount of negative publicity surrounding the crisis, and whether or not the affected brand had to acknowledge blame.

Advertising $\times$ Negative Publicity. Traditionally, researchers posited that negative publicity can damage brand equity (Dawar and Pillutla 2000; Liu and Shankar 2012) and credibility (Erdem and Swait 1998), and hence the effectiveness of brand advertising. More recently, however, Berger et al. (2010) have shown that, in some instances, negative publicity may increase product awareness. It is argued that the heightened brand awareness and media attention translates in a higher return on advertising investments than if they were part of routine equity-building activities (Dawar 1998). Moreover, Wang (2006) has shown that inconsistent messages in product publicity versus advertising increase the perceived message believability for advertising, because consumers are more motivated to process the information in an attempt to 
reconcile the differences (Maheswaran and Chaiken 1991). Moreover, because of the media scrutiny, customers may focus their attention on the focal or similarly categorized brands, which could also enhance their ad effectiveness (Rubel, Naik and Srinivasan 2011). As such, negative publicity can increase advertising effectiveness for the brand and/or category. Following this line of reasoning, we expect:

H1: The effectiveness of brand advertising is higher when there is a higher level of negative publicity surrounding the crisis.

H2: The effectiveness of category advertising is higher when there is a higher level of negative publicity surrounding the crisis.

Price $\times$ Negative Publicity. Apart from a tremendous impact on brand equity (Dawar and Pillutla 2000) and firm credibility (MacKinsey and Lutz 1989), negative publicity may also decrease the perceived differentiation of the affected brand (Ahluwalia et al. 2000). Indeed, the brand's relative position in the category might have been negatively affected (Leclerc, Hsee, and Nunes 2005) because consumers might now classify it in a lower-quality tier, which could lead to an increase in the magnitude of its price elasticity (Boulding, Lee, and Staelin 1994). Moreover, the consistency of the brand's quality signal has been affected (Erdem, Swait, and Louviere 2002). Because of these reasons, we expect:

H3: Brand price sensitivity is higher when there is a higher level of negative publicity surrounding the crisis.

Given that negative news may also affect the equity of non-affected brands (Roehm and Tybout 2006), we expect a similar effect for category price: 
H4: Category price sensitivity is higher when there is a higher level of negative publicity surrounding the crisis.

Advertising $\times$ Blame. A brand's equity is a function of consumers' confidence in the brand's ability to fulfill expected/promised benefits (e.g., Aaker 1996; Keller, 1993). As put by Gürhan-Canli and Fries (2010), branding is about creating and consistently delivering a promise to its target customers. The product crisis may lead customers to question this ability (Dutta and Pullig 2011). By acknowledging blame for the product-harm crisis, a firm makes clear that it failed to fulfill its promise (Riordan, Marlin, and Kellogg 1983). Put differently, "concomitant confirmation of guilt should lower trust by making clear that the mistrusted party was to blame" (Kim et al. 2006, p.51). This reduced trust translates in a lowered post-crisis advertising effectiveness for the brand. We therefore hypothesize:

H5: The effectiveness of brand advertising is lower when the affected brand acknowledges blame than when it does not.

If the focal brand admits blame, it means that one of the category members (rather than an external party) is to blame (Siomkos et al. 2010). Moreover, consumers frequently question the motivations of marketing actions. When competitors launch extra advertising campaigns in the aftermath of a crisis, consumers may believe this to be an opportunistic attempt to take advantage of the misfortune of the "wounded" brand (Siomkos et al. 2010), especially when the latter's position has suffered even more because of a forced blame acknowledgement. Given that inferred motivations influence the effectiveness of advertising spending (Campbell 1999; Eeagly, Wood and Chaiken 1978), we hypothesize: 
H6: The effectiveness of category advertising is lower when the affected brand acknowledges blame than when it does not.

Price $\times$ Blame. Confirming guilt makes clear that the mistrusted party is to blame, which lowers a brand's credibility substantially (Kim et al. 2006). A lower brand credibility increases the required information search and processing costs, and reduces the perceived quality of the brand (Erdem et al. 2002), both of which increase its price sensitivity. Thus, we hypothesize:

H7: Brand price sensitivity is higher when the affected brand acknowledges blame than when the brand does not.

As before, acknowledging blame by one brand may taint competitors by association (Siomkos et al. 2010). Therefore:

H8: Category price sensitivity is higher when the affected brand acknowledges blame than when the brand does not.

\section{Control Variables}

Consumer heterogeneity. To account for heterogeneity across consumers, we control for a household's pre-crisis brand loyalty and category usage. Arguments can be formulated for both a positive and a negative impact of brand loyalty and category usage on how consumers react to a crisis. On the one hand, consumers with positive attitudes toward a target are not only likely to resist counterattitudinal crisis information, they also weigh this information less in their product evaluations (Ahluwalia et al. 2000). Hence, they may react less negatively to the crisis. On the other hand, extremely negative information has been shown to be highly diagnostic (Herr et al. 1991), and might therefore be hard to refute (Ahluwalia et al. 2000). Moreover, Grégoire and Fisher (2008) show that customers who are treated poorly by a firm with which they feel a strong 
connection can feel even more disconcerted and hurt than others because of a greater sense of betrayal. When a similar "love becomes hate" effect happens in a product-harm crisis, brand loyalty and category usage will have a negative impact on brand share and category purchases.

Price premium. Brands with a high price premium tend to have a higher brand equity, and thus typically have very committed consumers (Aaker 1996). This may offer resilience in the face of misfortune (Hoeffler and Keller 2003). Indeed, committed consumers are more likely to counterargue with negative information (Ahluwalia et al. 2000), while they attempt to confirm prior expectations (Dawar and Pillutla 2000). On the other hand, the likelihood that the crisis is noticed is higher for high-equity brands given that they receive more media attention, and given that consumers tend to pay more attention to, and retain more information on, familiar brands (Hoeffler and Keller 2003). Also the category may suffer more from a crisis affecting a premium brand, given that negative information on these brands generates more attention (Hoeffler and Keller 2003). Therefore, product harm for a premium brand is more likely to spill over to the category (Roehm and Tybout 2006).

Number of affected brands. A particular product-harm crisis may affect multiple brands because of, e.g., a shared manufacturer or ingredients' supplier. The effect on category purchases of a crisis including multiple brands is likely to be larger, as it becomes more likely that the crisis reflects an industry-wide (production) problem (Roehm and Tybout 2006). Also, a larger fraction of the customer base will find their most preferred brand taken from the shelves, making them more likely to defect from the category (Campo, Gijsbrechts, and Nisol 2003). In contrast, we expect the impact on the share of each individual brand to be smaller, because the attention will 
be focused less on any single brand, and also the set of unaffected brands that consumers can switch to becomes smaller.

Private label versus national brand. Store brands are perceived inferior in quality than national brands (Ailawadi, Neslin, and Gedenk 2001b; Steenkamp, Van Heerde, and Geyskens 2010). Therefore, quality expectations for private labels are lower, and a product-harm crisis will be less likely to be perceived in conflict with the quality signal of the brand (Zhao et al. 2011). We thus expect the loss in brand share after a crisis to be smaller for private labels. In addition, the distribution of private labels is more limited compared to national brands. Therefore, we expect the impact of a private-label recall on category purchases to be smaller.

Competition density. To account for differences in category structure across product-harm crises, we control for pre-crisis competition density. In the literature, the extent of concentration of the brands in the market has been shown to be an important antecedent of market conduct and outcomes (Steenkamp et al. 2005). Finally, we control for differences between the (two) countries we study by including a country dummy.

\section{MODEL}

As argued before, a product-harm crisis may not just impact the brand itself, but also the entire category. Therefore, our key focus is on the changes in households' brand shares and category purchases, across a large panel of households. To adequately capture both dependent variables, our modeling approach should address four issues. First, the model should account for heterogeneity across households. Second, the model should account for the potential endogeneity of the marketing variables. Third, the approach should allow for potential correlations between (i) observations of the same household across different product-harm crises, and (ii) between 
observations of different households within the same product-harm case. Finally, the measures should capture enough purchases for reliable estimation of brand shares and category purchases.

We now discuss how we address each of these issues. First, individual-level consumption is influenced by a number of fixed consumer characteristics. To control for this source of heterogeneity across households, we use a difference approach, and model the difference between a household's post- and pre-crisis brand share and category purchases. This approach is similar in spirit to a fixed-effect approach that controls for unobserved time-invariant effects of the cross-sectional units (indeed, by differencing, the time-invariant or fixed effects disappear). This approach was followed, e.g., in Ailawadi, Lehmann and Neslin (2001a) to control for brand-specific fixed effects while examining the impact of a major policy change. As we will consider full (all batches across the entire country) product recalls, no control group can be considered, precluding the difference-in-difference approach used in Ailawadi et al. (2010).

Second, omitted variables may cause the marketing variables to be correlated with the error terms for both the brand-share and category-purchase model. Indeed, managers may base their advertising and pricing response on factors observed by them but not by the researcher. To accommodate potential endogeneity of advertising, price and all interaction effects involving these marketing variables, we use a 2SLS estimation technique (see, e.g., Ebbes, Papies and Van Heerde 2011 for a recent review on endogeneity issues in marketing). As a by-product of the estimation, we obtain the first-stage regression results for the endogenous regressors price and advertising. Although these first-stage results are not of primary interest, they do give some insights into the dynamic price and advertising responses in the wake of a product-harm crisis (see also Shaver (2005, pp.338-339) for the recommended use of 2SLS for an endogenous 
mediator, as well as Leenheer et al. (2007) and Ataman et al. $(2008,2010)$ for recent marketing applications of this procedure). We discuss these effects in the Results Section.

Third, the changes in brand share and category purchases are both measured for a given crisis and household. One particular household is likely to be observed in multiple crisis cases, while each crisis case affects multiple households. In line with the recommendation of Mizik and Jacobson (2009), we use a robust clustered error-term estimation. Specifically, we adopt the procedure proposed by Lin (1994), and the extension to two-way clustering in Cameron, Gelbach, and Miller (2011) to estimate robust standard errors.

Finally, to obtain reliable measures for the changes in brand share and category purchases, we want to use a sufficiently long period prior and after the crisis to ensure that we observe enough purchases in both periods. In line with Gielens and Steenkamp (2007), and given that we study frequently purchased consumer goods with differing interpurchase times, we use an observation period of one year before and one year after the crisis. Moreover, prior research on product-harm crises (e.g., Van Heerde et al. 2007) has shown that the dust inherently surrounding such crisis situations has settled well within a year after the crisis. We offer more details on the exact operationalizations of the variables in the Data Section.

\section{Model Specification}

Following an established tradition in the market-response literature (see, e.g., Leeflang et al. 2000, p.167), we decompose sales into primary demand (category purchases) and selective demand (brand share). We use a regression framework to assess the impact of crisis characteristics, marketing variables, control variables, and the interaction effects. The (transformed $)^{3}$ change in brand share for household $i$ and crisis $j$ is modeled as: 


$$
\begin{aligned}
\Delta B S_{i j}^{*}= & \beta_{0}^{B S}+\beta_{1}^{B S} \text { Publicity }_{j}+\beta_{2}^{B S} \text { Blame }_{j} \\
& +\beta_{3}^{B S} \Delta \text { Relative brand advertising }_{j}+\beta_{4}^{B S} \Delta \text { Relative brand price }_{j} \\
& +\beta_{5}^{B S} \Delta \text { Relative brand advertising }_{j} \times \text { Publicity }_{j}+\beta_{6}^{B S} \Delta \text { Relative brand price }_{j} \times \text { Publicity }_{j} \\
& +\beta_{7}^{B S} \Delta \text { Relative brand advertising }_{j} \times \text { Blame }_{j}+\beta_{8}^{B S} \Delta{\text { Relative brand } \text { price }_{j} \times \text { Blame }_{j}} \\
& +\beta_{9}^{B S} X_{1 i j}+\varepsilon_{i j}^{B S}
\end{aligned}
$$

where the $X_{1 i j}$ vector includes the control variables, i.e., brand loyalty, price premium, number of affected brands, a private-label dummy, competition density and a country dummy variable $(1=$ the Netherlands, $0=\mathrm{UK}$ ). Similar to the brand-share model, the (transformed) ${ }^{4}$ change in category purchases for household $i$ and crisis $j$ is specified as:

$$
\begin{aligned}
\Delta C P_{i j}^{*}= & \beta_{0}^{C P}+\beta_{1}^{C P} \text { Publicity }_{j}+\beta_{2}^{C P} \text { Blame }_{j} \\
& +\beta_{3}^{C P} \Delta \text { Category advertising } \\
j & +\beta_{4}^{C P} \Delta \text { Category price }_{j} \\
& +\beta_{5}^{C P} \Delta \text { Category advertising }_{j} \times \text { Publicity }_{j}+\beta_{6}^{C P} \Delta \text { Category price }_{j} \times \text { Publicity }_{j} \\
& +\beta_{7}^{C P} \Delta \text { Category advertising }_{j} \times \text { Blame }_{j}+\beta_{8}^{C P} \Delta{\text { Category } \text { price }_{j} \times \text { Blame }_{j}} \\
& +\beta_{9}^{C P} X_{2 i j}+\varepsilon_{i j}^{C P}
\end{aligned}
$$

where $X_{2 i j}$ are the control variables category usage, price premium, number of affected brands, the private-label dummy, competition density and the country dummy.

\section{Model Estimation}

To accommodate the potential endogeneity of advertising, price and the interaction effects involving these marketing variables, equations (1) and (2) are estimated with 2SLS. We use five broad categories of instrumental variables (IVs). Table 1 summarizes the main IVs used for each model, and indicates the operationalization and data source.

In line with Villas-Boas and Winer (1999) and Dhar and Hoch (1997), we use the lagged changes in the marketing variables as a first set of IVs. Given that the marketing variables measure the change in the year following the crisis when compared to before, the IVs capture the 
corresponding change in the two years preceding the crisis. Second, we include the lagged changes in the relevant performance metrics (i.e., change in brand share for the affected brandshare model, and change in category purchases for the category-purchases model). These IVs capture the fact that the main drivers of marketing changes are demand-based (Srinivasan, Pauwels, and Nijs 2008). In the third set of IVs, we use a number of variables to capture the evolution in the overall production costs following the recommendation of Luan and Sudhir (2010). To that extent, we account for changes in the overall consumer price index, fuel prices (see, e.g., recent work by Ma et al. 2011 for the importance of this factor in the marketing adjustments of retailers), labor costs, and rental prices. Fourth, in line with Ma et al. (2011), we include a fixed-effects correction to account for systematic differences between major groups not yet captured by the previous sets of IVs. Following Steenkamp et al. (2010), we control for differences between beverages and other categories. As a final set of IVs, we include the interaction effects of all IVs identified above with Negative Publicity and Blame. Following Wooldridge 2002, pp.121-122 and Luan and Sudhir (2010), these IVs are included because the models include interactions between exogenous variables (the two crisis characteristics) and endogenous variables (advertising and price). In the results section, we report tests that confirm the strength and validity of the IVs.

\section{DATA}

To calibrate the models, we have collected a unique and comprehensive data set. We study all major FMCG product-harm crises that happened in the UK and the Netherlands between 2000 and 2007. We define "major" in the sense that all units of at least one variety are fully recalled. Hence, we exclude cases in which only certain batches are recalled. Using the recall records of 
governmental and consumer organizations, ${ }^{5}$ we identified sixty major (voluntary) product recalls in this period, thirty-six of which took place in the UK and twenty-four of which in the Netherlands. We study a large range of product-harm crises ranging from cereals to ice cream, and from mineral water to liquor. Examples of cases include salmonella-contaminated Cadbury dairy milk chocolate, the detection of glass inside Olvarit baby food, pieces of plastic in Basset's milky babies (lollies), and bursting bottles of Bacardi Breezer pre-mixed spirits. Since several of these product-harm crises affect the same category, we identify forty unique cases for the category-purchase model. A description of all cases can be found in the Appendix.

We combined data from different sources. We obtained household scanner data for these crises from TNS UK (gross panel size $=25,000$ households) and GfK The Netherlands (gross panel size $=6,000$ households). Advertising expenditure data for all relevant brands and categories were purchased from AC Nielsen UK and The Netherlands. Furthermore, we obtained information on crisis characteristics from the recall announcements and through an extensive media search on the specific crisis cases in the top newspapers using the Lexis Nexis (Netherlands) and Factiva (UK) databases. ${ }^{6}$ All variables are gathered during the period of one year before and one year after the crisis. In line with Cleeren et al. (2008), the start of the crisis is the date mentioned on the official recall announcement, and the end of the crisis is the date of the first purchase of the affected variety in the household panel after the start of the crisis. For all cases, all batches of the affected variety were recalled at the same time. As such, the start of the crisis could easily be identified, and it applied to all panel members. 


\section{Dependent Variables}

The change in category purchases for household $i$ in crisis $j$ is the difference between a household's category-purchase volume in the year after versus the year before the crisis. The difference approach controls for potential heterogeneity across households (e.g., Ailawadi et al. 2001a; Cameron and Trivedi 2005). To make our purchase measure comparable across categories, we divide the change by the average of the category purchases $(C P)$ before and after:

$$
\Delta C P_{i j}=\frac{C P_{i j}^{A F T E R}-C P_{i j}^{\text {BEFORE }}}{\left(C P_{i j}^{\text {BEFORE }}+C P_{i j}^{A F T E R}\right) / 2} .^{7}
$$

For the category-purchase model, our sample consists of all households that made at least three purchases in the category during the total observation period (one year before until one year after the crisis). This ensures we exclude the very light or accidental users of the category. Obviously, not every customer was "active" (i.e., had three purchases in the observation period) in every category (indeed, only households with small children will buy baby food, and not every household will have three purchases of a particular type of liquor). On average, panelists were active in seven categories. Per category, an average of about 10,300 households was available, leading to a total number of 411,266 observations for the category-purchase model (Equation 2).

For the brand-share model, we select households who make at least three purchases of the affected brand within the observation period of two years (one year prior, one year after). This is again done to exclude very light or accidental brand buyers. As not every consumer in a category will buy the affected brands, the sample sizes are lower in the brand-share equation. On average, panelists contributed two observations to the brand-share equation. Approximately 746 observations were available for each of the sixty affected brands, for a total of 44,743 observations for the brand-share equation (1). 
The change in affected brand share for household $i$ and crisis case $j$ is defined as the difference between the volume share of the affected brand in the category purchases during one year after and one year before the crisis: ${ }^{8}$

$$
\triangle B S_{i j}=B S_{i j}^{A F T E R}-B S_{i j}^{B E F O R E} .
$$

We provide the definitions and summary statistics for the dependent and independent variables in Table 2.

\section{Crisis Characteristics}

Crisis characteristics are based on the media search we conducted. Negative publicity is measured as the fraction of newspapers among the (country-specific) considered set that reported on the crisis. The salmonella contamination in Cadbury chocolate was covered by all 17 newspapers in the research set, while only one newspaper covered the bursting Bacardi Breezer bottles. Blame is a dummy variable, indicating whether the company acknowledged the blame for the crisis either in the recall announcement or in the surrounding publicity. While, for example, Bacardi-Breezer's recall announcement attributed the blame of the bursting bottles to its packaging supplier, Cadbury acknowledged that the salmonella contamination in their chocolate was due to a problem in their own production process.

\section{Marketing Variables}

For the marketing variables in the brand-share equation (1), we use the change in relative advertising and relative price (see e.g., Leeflang et al. 2000; Zenor, Bronnenberg and McAlister 1998). The change in relative brand advertising is specified as the difference between the postand pre-crisis share of voice, expressed relative to the expenditures of the five largest nonaffected competitors and the brand itself. ${ }^{9}$ The change in relative brand price is defined as the 
difference between the relative brand price (per volume unit) after and before the crisis, expressed relative to the weighted average price of the five main non-affected competitors. Given that the recorded prices are net prices, they also reflect the discounts that brands may have offered after the crisis.

For the category-purchase equation (2), we use the change in total category advertising expenditures (Schultz and Wittink 1976) and average category price (Nijs et al. 2001) per volume of all affected brands and the five largest non-affected competitors. To make these measures comparable across categories, we divide them by the average of total advertising expenditures before and after, and average price before and after, respectively.

\section{Control Variables}

The price premium is measured as the difference between the (weighted) average price of the affected brand(s) and the least expensive private label in the category (see Ailawadi, Lehmann, and Neslin 2003 for a similar practice). To standardize the measure over the different categories, we divide this difference by the affected brand's price before the crisis. Because of potentially different effects of crises involving multiple brands, we account for the number of affected brands in the crisis. We account for the effect of private label with a dummy variable that indicates whether the affected brand was a private label (PL).

Our measures for household heterogeneity ((brand) loyalty and (category) usage) are based on the household-panel scanner data during the initialization period (one year before the crisis). We explicitly choose to measure these household characteristics prior to the crisis to avoid a confound with the dependent variable brand share and category purchases. In line with Cleeren et al. (2008), we specify pre-crisis (behavioral) loyalty to the affected brand as its 
within-household market share (in volume), while we operationalize category usage as the precrisis total volume purchased in the category (normalized by the category average across households). Finally, in line with Moorman et al. (2012), we control for the competition density within the affected category with the sum of market shares of the largest four players in the market (C4), and include a country dummy for the Dutch cases to control for potential differences between the two examined countries, i.e., the UK and The Netherlands.

Following Steenkamp et al. (2010), we group mean-center the household characteristics (within crisis cases), and grand-mean center all other continuous independent variables (across crisis cases).

\section{RESULTS}

We first tested the extent of multicollinearity in the models. In Table 3, we report the correlations between the different crisis characteristics, which are all 0.62 or less, well below 0.8 (cf., Judge et al., 1998, p.868). The maximum VIF value in the brand-share model is 5.68, and 2.38 for the category-purchase model. Both values are well below 10 (Hair et al. 2010, p.204), mitigating multicollinearity concerns.

In addition, we tested both the strength and validity of our IVs (in line with the recommendations of Bascle 2008). To check for the strength of the IVs, we used the AngristPischke (2009, pp.217-218) multivariate $F$-statistic which is recommended in applications with multiple endogenous variables. In both the market-share and category-purchases model, the $p$ values corresponding to the multivariate $F$-statistic in all first-stage regressions are smaller than 0.01 , rejecting the null hypothesis that the IVs do not explain the endogenous variables. In other words, the IVs are sufficiently strong. As for the validity condition, the Hansen $J$ test (which is 
robust to clustered error terms) is not significant for both models $(p>0.15)$. This indicates that the null hypothesis that the IVs are uncorrelated with the error term, cannot be rejected. In other words, the IVs are sufficiently valid. Tables 4 and 5 show the parameter estimates for the brandshare (1) and category-purchase equation (2).

\section{Crisis characteristics}

While the impact on the affected brand's share is not significant $(\beta=.079 ; p>.1)$, the category benefits from blame acknowledgement by the affected brand $(\beta=1.173 ; p<.01)$. By acknowledging blame, the other brands in the category have been moved out of harm's way. The extent of negative publicity, however, has no significant main effect on either the change in brand share $(\beta=.001 ; p>.1)$ or category purchases $(\beta=.423 ; p>.1)$. The inherent negative impact of the bad news surrounding the crisis (Herr et al. 1991) may be nullified by the increase in awareness caused by the mere mentioning of the brand or category (Berger et al. 2010).

\section{Marketing variables and interactions}

The change in relative brand advertising has the expected positive impact on the change in brand share $(\beta=.535 ; p<.01)$, while the change in relative brand price is not significant ( $\beta=.292 ; p>.1$ ). With regard to the category, we find that both category advertising $(\beta=.813 ; p<.01)$ and category price $(\beta=-5.827 ; p<.1)$ have the expected significant effects. Advertising $\times$ Negative Publicity. Negative publicity increases the brand's advertising effectiveness $(\beta=1.221 ; p<.1)$, consistent with the heightened brand awareness identified in Berger et al. (2010). It also enhances category advertising effectiveness $(\beta=3.373 ; p<.1)$. These findings are consistent with H1 and H2, confirming Dawar's (1998) proposition that 
increased media attention in a crisis context might not be all bad for companies given that it could translate in a higher return on advertising investments.

Price $\times$ Negative Publicity. Negative publicity has no significant effect on the price sensitivity of brand share $(\beta=.006 ; p>.1)$, rejecting H3. However, we do find support for H4, because the price sensitivity of post-crisis category purchases increases with the extent of negative publicity $(\beta=-13.154 ; p<.05)$. This corroborates the notion that the crisis causes a loss in equity for the category as a whole (Roehm and Tybout 2006), making consumers more price sensitive.

Advertising $\times$ Blame. When the affected brand takes the blame for the crisis, its advertising effectiveness decreases $(\beta=-.456 ; p<.05)$, supporting H5. This finding is consistent with a loss in trust in the brand's ability to fulfill its promises (Aaker 1996; Keller 1993). We also find that category advertising becomes less effective when the affected brand has taken the blame for the crisis ( $\beta=-2.053 ; p<.01$ ), supporting H6. When a category member (rather than some outside party) was responsible for the crisis, the credibility for the whole category may be affected, while also the underlying motive for competitors' advertising may be questioned.

Price $\times$ Blame. Price sensitivity increases following blame acknowledgement ( $\beta=-.962 ; p<.1$ ), supporting $\mathrm{H} 7$. When a brand acknowledges guilt in a crisis, brand credibility decreases (Kim et al. 2006). This has a negative impact on the effectiveness of both marketing variables (Erdem et al. 2002). Interestingly, category price sensitivity is not influenced by blame acknowledgement $(\beta=5.158 ; p>.1)$, which is at odds with $\mathrm{H} 8$. 


\section{Control Variables}

The household characteristics brand loyalty and category usage have significant negative effects on the change in brand share $(\beta=-1.838 ; p<.01)$ and category purchases $(\beta=-.728 ; p<.01)$. Thus, the decrease in brand share is especially strong for brand loyals when a product-harm crisis strikes. Similarly, the category purchases by heavy users are especially vulnerable to such a crisis. These results are in line with Grégoire and Fisher (2008), who showed that consumers with a strong connection to a brand or category feel a stronger sense of betrayal and hurt when treated poorly.

While both the price premium and the number of affected brands have no significant effect on either the change in brand share (respectively, $\beta=-.138 ; p>.1$ and $\beta=-.002 ; p>.1$ ) and category purchases (respectively, $\beta=-.081 ; p>.1$ and $\beta=.025 ; p>.1$ ), the type of brand matters in both models. Indeed, private labels suffer less from product harm $(\beta=.141 ; p<.1)$, in line with their lower quality expectations (Zhao et al. 2011), while the spillover to the category is reduced, in line with the more limited distribution of private labels $(\beta=1.125 ; p<.01)$. Although brands suffer more when the category is more concentrated $(\beta=-.257 ; p<.05)$, competition density has no significant impact on the category $(\beta=-.686 ; p>.1)$. In highly-concentrated markets, each of the competing (non-affected) brands is more powerful (Nijs et al. 2001), and better able to take advantage of the weakened position of the affected brand. This may explain the higher brand-share loss in concentrated settings. Finally, while the change in brand share is not significantly different in the two included countries $(\beta=-.025 ; p>.1)$, category purchases decrease more in The Netherlands $(\beta=-.506 ; p<.05)$. 


\section{First-stage Regression Results}

We obtain first-stage regression results for the endogenous price and advertising variables as a function of the exogenous variables, including characteristics of the product-harm crisis, and the IVs. Although these auxiliary results are not of primary interest, they do give insights into the dynamics of price and advertising responses in the wake of the crisis. ${ }^{10} \mathrm{We}$ find that brands increase their advertising in case they are to blame for the crisis $(p<.05)$, which supports the idea that firms feel that a stronger corrective action is required in such instances (Chen et al. 2009). Moreover, an affected brand reacts less in concentrated markets both in terms of advertising $(p<.01)$ and price cuts $(p<.10)$. In concentrated markets, profit margins tend to be higher (Steenkamp et al.2005), and companies may be less motivated to cut prices, as this could cause these attractive high margins to dissipate (Ramaswamy, Gatignon, and Reibstein 1994). In contrast, brands use more price cuts to differentiate themselves more from other affected brands in case several of them are affected $(p<.05)$.

We find that competitors choose not to retaliate with advertising when there is a lot of publicity surrounding the crisis $(p<.01)$, or when the affected brand is strong, as shown by a high price premium $(p<.01)$. Indeed, the damage to the category in these cases may be so severe that advertising messages may no longer be able to restore the lost trust, and companies may feel it better to stay out of the public's eye. Also in highly concentrated markets, competitors are less likely to react with advertising $(p<.05)$. Moreover, competitors especially try to attack affected private labels with price cuts $(p<.01)$, while they do less so when the crisis involves more affected brands $(p<.01)$. 


\section{Additional Model Checks}

We now report on a number of additional model checks to study the robustness of our results to our modeling choices. First, we checked the correlation between the error terms $\varepsilon_{i j}^{B S}$ and $\varepsilon_{i j}^{C P}$ of the brand-share equation (1) and the category-purchase equation (2), respectively. Because the sample sizes for the estimation of these equations differ ( $\mathrm{N}=44,743$ for the brand-share equation and $\mathrm{N}=411,266$ for the category-purchase equation), we can only calculate the correlation across the overlapping observations. The error correlation turns out to be small: -.109. Hence, the potential for efficiency gains (lower standard errors) from estimating the two equations simultaneously with a SUR-type of approach is very limited (see Chandrashekaran and Sinha 1995, p.446 for a similar reasoning).

As a second robustness check, we checked how brand share and category purchases are affected by other potential drivers, such as the length of the recall period, the year of the crisis, and the underlying cause of the crisis. Consumers may use the length of the recall period as a sign of the severity of the problem given that companies may need a longer time to overcome more serious problems. On the other hand, too short recall periods may also be perceived as untrustworthy. We find no evidence for such effects since neither the recall period nor its square are significant $(p>.1)$. Furthermore, we controlled for the year of the crisis. The number of crises increases every year (PWC 2006), which may cause different consumer reactions to recent recalls compared to older cases. However, the year of the crisis did not have a significant effect on the change in brand share or category purchases $(p>.1)$.

We also tested whether yet another indicator of the severity of the crisis (besides the ones that are already in the model) has an impact on consumer decisions. We identified three different 
types of crises, i.e., (i) content-related problems, (ii) labeling mistakes, and (iii) package failures. In order to test for the impact of the type of the crisis, we added two dummy variables indicating whether the crisis was of type $\mathrm{i}$ and type $\mathrm{ii}$, respectively. None of the dummy variables was significant in either of the models $(p>.1)$.

Third, we zoomed in on our operationalization of the marketing variables. Marketing activities of the five leading non-affected brands are reflected in our current operationalizations. Indeed, in the brand-share model, competitive advertising and price are captured in the denominator of the relative variables, while for category purchases we use the combined (i.e., the sum or average) marketing efforts of the affected and five largest non-affected brands. An alternative (but less parsimonious) specification is one in which the own effect is modeled separately from the cross effects. We estimated a (main-effects-only) model with separate endogenous own and (combined across all competitors) cross effects. ${ }^{11}$ Splitting the own and cross-effects leads to an increase in the root MSE from 0.901 to 0.902 for the brand-share, and from 3.508 to 3.515 for the category-purchases model, and hence did not result in an improved fit relative to our specification.

In the absence of a control group, one cannot assess what would have happened if the product-harm crisis had not taken place. Still, to approximate this scenario, we re-ran our models while controlling for the $t$-values of pre-crisis trends in brand share and category purchases (see Pauwels and Hanssens (2007) for a similar practice). These $t$-values capture the direction and extent of pre-crisis tendencies in brand share and category purchases. None of these trend terms was significant $(p>.1) .^{12}$ 


\section{CONCLUSIONS}

Product-harm crises occur ever more frequently in today's marketplace, and they can seriously damage both the affected brand and the category as a whole. Managers of both affected and nonaffected brands often increase their advertising support or decrease their price substantially in the wake of a product-harm crisis in an attempt to regain lost customers, or to benefit from the misfortune of their competitor(s). An alternative strategy is to hike prices in an effort to safeguard the brands' revenues. However, little is known on the relative effectiveness of these strategies. Indeed, prior studies that quantified the post-crisis effectiveness of marketing adjustments using actual consumer-purchase data following a real-life crisis (as opposed to stated intentions following a description of a hypothetical crisis) primarily focused on one single crisis, i.c., a peanut-butter contamination case in Australia. As such, generalizable knowledge on the phenomenon is still missing, especially on the moderating impact of crucial crisis characteristics such as the amount of negative publicity and blame acknowledgement.

In this paper, we extend the existing knowledge base considerably, as we analyze, using large household-scanner data sets, sixty major FMCG product-harm crises that recently happened in the UK and the Netherlands. We examine, at the individual-household level, how brand share and category purchases change in the year after the crisis compared to the year before, and relate this change to crisis characteristics (i.e., negative publicity and blame acknowledgement), marketing variables (i.e., price and advertising), and their interaction effects. We thus obtain a contingency framework informing us what marketing actions work more or less under what type of crisis. This framework not only contributes to the theoretical knowledge base on product-harm crises by exploring various boundary conditions to previous main-effects-only 
results, but also makes the recommendations for managers confronted with a specific crisis scenario much more actionable.

Our empirical findings show that the effects are much more intricate than a sole focus on the main effects would suggest. Looking at the main effect of blame acknowledgement, one might feel acknowledging blame is to be recommended: no negative main effect is observed on the acknowledging brand's market share, while the category as a whole benefits. Taking the interaction effects into account, however, clearly shows that there is no such thing like a free lunch. Van Heerde et al. (2007) already warned for two additional jeopardies brand managers face when their brand is involved in a product-harm crisis: a decrease in advertising effectiveness (making it more difficult to recover lost market positions) and an increased price sensitivity (making it more difficult to raise prices to safeguard revenues). Our results show that these additional jeopardies become particularly pronounced when the brand was to blame. While managers tend to feel an even stronger urge to increase their advertising support when the crisis was their fault, the effectiveness of that marketing variable is more seriously damaged if blame had to be acknowledged. Hence, the risk of "spoiled arms" (Leeflang and Wittink 1996; Steenkamp et al. 2005) increases considerably once blame has to be taken.

Also for competitors, increasing their advertising may be a double-edged sword. Some non-affected competitors see the crisis as an opportunity, and ramp up their advertising. For example, Michelin North America hiked up its advertising budget to run a print campaign emphasizing tire safety and quality following Bridgestone/Firestone's 2000 recall of 6.5 million tires following accidents involving defective tires (Advertising Age 2000). More recently, GM launched a campaign offering Toyota owners an extra $\$ 1,000$ rebate to switch following 
Toyota's repeated recalls (Valdes-Dapena 2010). Our findings show that such a strategy will not work, and may even backfire, if the affected brand had to publicly acknowledge blame. Indeed, the effectiveness of category advertising under the blame condition is significantly reduced. Hence, consumers may see the competitors' strategy of "chasing ambulances" as being overly opportunistic.

The findings involving the negative publicity surrounding product-harm crises are also intriguing. Prior studies often do not distinguish between the extent of negative publicity surrounding the event. For example, Dawar and Pillutla (2000) and Van Heerde et al. (2007) both define product-harm crises as well-publicizedevents wherein products are found to be defective or even dangerous (italics added). However, the extent of this negative publicity may differ widely across crises. While Morrison's recall of its tin-contaminated tomato soup was only covered in $18 \%$ of the major UK newspapers, the glass particles in Olvarit's baby food attracted the attention of all major Dutch newspapers. Interestingly, this differential coverage affects the effectiveness of the response strategies. Increased media scrutiny increases the price sensitivity of the category, making across-the-board price hikes to protect sales revenue more likely to backfire. However, in line with the theorizing of Berger et al. (2010), we find that an increase in post-crisis advertising becomes a more attractive option, both for the affected brand and for the category as a whole. Our finding of an increase in advertising effectiveness with more publicity is in line with the idea that the heightened awareness caused by the media attention tends to be more persistent than the negative valence of its content.

Table 6 offers recommendations for brands and categories faced with a product-harm crisis. Based on our results, it comments on the relative attractiveness of changes in the decision 
variables price and advertising under different crisis settings. Managers obviously hope to never be confronted with a product-harm crisis. But if they are, they would prefer that the blame is not theirs, and that the crisis does not generate a lot of negative publicity. We use that as our base case (first line in Table 6), and evaluate how to use advertising and price in different circumstances. Advertising appears to be a tool that indeed can be used to stimulate both primary and secondary demand (given the significance of the respective parameters). A price decrease, however, represents spoiled arms (Leeflang and Wittink 1996; Steenkamp et al. 2005), given that it will not lead to a corresponding increase in brand share. However, in the base case, price turns out to be an effective instrument to protect/stimulate category consumption.

Once the brand has to acknowledge blame and/or when the extent of publicity changes, the recommendations may change, as summarized in cases 2-4 of Table 6 . Table 6 identifies settings where advertising become more or less effective, and where price decreases may be used as an additional instrument to protect the brand or category. For example, in a low-publicity product-harm case, where blame had to be admitted, brands and categories are not advised to increase advertising, as the instrument becomes considerably less effective for both performance metrics. However, in the opposite case (high publicity, no blame) an advertising increase is definitely recommended. As for price, brand price decreases are only recommended when blame had to be acknowledged, whereas category price decreases are recommended in all cases, and even more so in case of high publicity.

While the focus of our analysis was on the actionable interaction effects between crisis characteristics and marketing adjustments, the control variables lead to some additional, managerially relevant, insights. First, our results warn managers to not take their most valuable 
customers for granted, i.e., the ones that showed most behavioral loyalty prior to the crisis and/or those that had a higher category usage. Indeed, these customers show a more negative reaction to the crisis, supporting the notion (see, e.g., Grégoire and Fisher 2008) that these customers feel particularly disconcerted because of the crisis. As lost trust is notoriously hard to recover (Nooteboom, Berger, and Noorderhaven 1997), this may well take a prolonged effort.

Our results also provide additional insights in the ongoing battle between private labels and national brands. Quite a number of crises in our sample involved private labels that had to be taken off the shelves. It is unclear whether this is due to an inherently lower quality (which makes them more prone to product-harm crises), or because it is logistically easier to recall all items from a single retailer than from multiple retailers (as would be the case when national brands are affected). Still, given the increasing presence of private labels, and the danger of spillover effects to the rest of the category (see also Szymanowski and Gijsbrechts 2012), this should be an additional concern to national-brand manufacturers: not only do private labels increasingly gain market share, frequent quality problems requiring a recall may undermine the consumers' confidence in the category, and hence erode category sales. This concern is mitigated somewhat, because we find that both the brand and the category are hurt less when the affected brand is a private label. This latter finding could be due to the more limited distribution of the private-label brands (so that only a smaller fraction of customers is exposed to the crisis), but could also be driven by the fact that consumers a priori expect lower quality with private labels (which reduces the signaling value of the crisis). However, given their higher frequency, private-label-induced product-harm crises may well contribute considerably to the war chest national-brand managers 
should put together in anticipation (see Rubel et al. 2011 for an in-depth discussion on this issue) of a crisis hitting their category, which is hardly a comforting thought.

While we provide new, actionable insights on how to overcome a product-harm crisis, this research is subject to some limitations that offer opportunities for future research. One limitation is that we study product-harm crises in the context of FMCGs. The frequent-purchase nature of these goods allows consumers to adjust their purchase behavior rapidly, which can be readily observed in the type of household scanner panels we used for this study. The question is whether purchase behavior for recalled products with longer interpurchase times (e.g., durables think Toyota) shows a similar adjustment pattern, and the same sensitivity to the drivers as we observed (see e.g., Liu and Shankar 2012 and Thirumalai and Sinha 2011 for recent research on the impact of recalls in the automobile- and medical-device industries, respectively).

Moreover, our sample of crises consisted of cases in which at least one variety was fully recalled, and the recall was voluntary in all instances. We thus excluded from our analyses cases which were more limited in extent and potentially issued in different batches. In addition, since our sample solely consisted of voluntary recalls, we were not able to examine the difference between voluntary and forced recalls. Insights for these types of crises might be different, which may also be the case if the crisis was so extreme that it led to (multiple) casualties.

In line with earlier research in the marketing-mix effectiveness arena (see, e.g., Leeflang et al. 2000 for a review), we looked at both primary and selective demand. However, also other sales decompositions could be considered. For example, one could incorporate intervention (crisis) dummies in the modeling framework of Bucklin, Gupta, and Siddarth (1998) to assess 
whether marketing's influence as a driver of consumers' category incidence, brand-choice and quantity decisions changes when faced with a product-harm scenario.

Moreover, it could be interesting to study the origin of the product-harm crisis. When different brands (e.g., private labels and national brands) are manufactured in the same plant, this may affect the magnitude of spillover effects. However, it is very difficult (if not impossible) to control for this phenomenon in the empirical analysis. For example, retailers and NB manufacturers are very secretive as to who is involved in PL production (Kumar and Steenkamp 2007; Gomez-Arias and Bello-Acebron 2008). Since this information is also unavailable to the population at large, there is little a priori reason to expect spillover effects between specific NBs and PLs on the assumption that they could be produced in the same plant.

More research is also needed on how national-brand manufacturers should react to a product-harm crisis with private labels. Given that retailers are both customer and competitor to national-brand manufacturers, even more care should be exercised not to display a too opportunistic behavior in case of private-label misfortune. Conversely, national-brand recalls have a strong positive impact on the private-label share in the category. Using an independentsample $t$-test, we found evidence of a more pronounced growth in private-label share after a crisis with a national brand $(t=2.509 ; p=0.017 ; d f=58)$. The product-harm crisis may induce some national-brand consumers to try out the private label, and subsequently some of them may stick with the private label even when the national brand becomes available again. A similar phenomenon was documented in Lamey et al. (2007) following an economic crisis. More research is needed on this phenomenon. 
Our study determines the effects of product-harm crises on both the core (the affected brand) and the next layer (the category). In theory, it is possible that the crisis within one category causes spillover effects onto other categories because of umbrella branding, complementarity or substitutability of categories, comparable inter-purchase times, common use of ingredients and/or similarities in manufacturing procedures. The effects on this further layer, however, are arguably smaller than the more focal effects, while the number of potential intercategory effects is potentially very large.

While we concentrate on the impact of the crisis on the category as a whole, one could also look at potential differences in the after-crisis performance of specific non-affected competitors. Depending on the initial positioning (e.g., because of a perceived similarity to the affected brand), some brands may be affected disproportionately. Because of the crisis, individual brand shares may shift substantially, which may, in turn, lead to changes in competitive structure. ${ }^{13}$ Finally, rather than focusing on the result in the year following the crisis, one could consider the more detailed (e.g., weekly) adjustments that take place shortly after the crisis to capture in more depth the dynamic interplay between different demand- and supply-side mechanisms.

Despite these limitations, we believe our study offers a number of new empirical generalizations about how product-harm crises affect consumer behavior. We hope that firms and categories that face the challenge to overcome a product-harm crisis benefit from our recommendations. 


\section{REFERENCES}

Aaker, David A. (1996), "Measuring Brand Equity across Products and Markets," California Management Review, 38 (3), 102-120.

Advertising Age (2000), "Firestone Woes Create Opportunity," September 18.

Ahluwalia, Rohini, Robert E. Burnkrant, and H. Rao Unnava (2000), "Consumer Response to Negative Publicity: The Moderating Role of Commitment," Journal of Marketing Research, 37 (2), 203-214.

Ailawadi, Kusum L., Donald R. Lehmann, and Scott A. Neslin (2001a), "Market Response to a Major Policy Change in the Marketing Mix: Learning from Procter \& Gamble's Value Pricing Strategy," Journal of Marketing, 65 (1), 44-61.

Ailawadi, Kusum L., Scott A. Neslin, and Karen Gedenk (2001b), "Pursuing the Value-Conscious Consumer: Store Brands versus National Brand Promotions," Journal of Marketing, 65 (1), 71-89.

Ailawadi, Kusum L., Donald R. Lehmann and Scott A. Neslin (2003), "Revenue Premium as an Outcome Measure of Brand Equity," Journal of Marketing, 67 (4), 1-17.

Ailawadi, Kusum L., Jie Zhang, Aradhna Krishna, and Michael W. Kruger (2010), "When Wal-Mart Enters: How Incumbent Retailers React and How This Affects Their Sales Outcomes," Journal of Marketing Research, 47 (4), 577-593.

Angrist, Joshua D. and Jörn-Steffen Pischke (2009). Mostly Harmless Econometrics. An Empiricist's Companion, Princeton, Princeton University Press.

Ataman, Berk, Carl. F. Mela, and Harald J. van Heerde (2008), "Building Brands," Marketing Science, 27 (6), 1036-1054.

Ataman, Berk, Harald J. van Heerde, and Carl. F. Mela (2010), "The Long-term Effect of Marketing Strategy on Brand Sales," Journal of Marketing Research, 47 (5), 866-882.

Bascle, Guilhem (2008), "Controlling for Endogeneity with Instrumental Variables in Strategic Management Research," Strategic Organization, 6 (3), 285-327,

Bass, Frank M., Norris Bruce, Sumit Majumdar, B. P. S. Murthi (2009), "Wearout Effects of Different Advertising Themes: A Dynamic Bayesian Model of the Advertising-Sales Relationship," Marketing Science, 26 (2), 179-195.

Basuroy, Suman, Subimal Chatterjee, and S. Abraham Ravid (2003), "How Critical Are Critical Reviews? The Box Office Effects of Film Critics, Star Power, and Budgets," Journal of Marketing, 67 (4), 103-117.

Berger, Jonah, Alan T. Sorensen, and Scott J. Rasmussen (2010), "Positive Effects of Negative Publicity: When Negative Reviews Increase Sales," Marketing Science, 29 (5), 815-827.

Boulding, William, Eunkyu Lee, and Richard Staelin (1994), "Mastering the mix: Do Advertising, Promotion, and Sales Force Activities Lead to Differentiation?," Journal of Marketing Research, 31 (2), 159-172.

Bucklin, Randolph E., Sunil Gupta and S. Siddarth (1998), "Determining Segmentation in Sales Response Across Consumer Purchase Behaviors ," Journal of Marketing Research, 35 (2), 189-197.

Cameron, A. Colin, Jonah B. Gelbach, and Douglas L. Miller (2011), "Robust Inference with Multi-Way Clustering," Journal of Business and Economic Statistics, 29 (2), 238-249.

Cameron, A. Colin and Pravin K. Trivedi (2005), Microeconometrics: Methods and Applications, Cambridge, Cambridge University Press.

Campbell, Margaret C. (1999), "Why Did You Do That?" The Important Role of Inferred Motive in Perceptions of Price Fairness," Journal of Product \& Brand Management, 8 (2), 145-152.

Campo, Katia, Els Gijsbrechts, and Patricia Nisol (2003), "The Impact of Retailer Stockouts on Whether, What and How Much to Buy, “ International Journal of Research in Marketing, 20 (3), 273-286. 
Chandrashekaran, Murali and Rajiv K. Sinha (1995), "Isolating the Determinants of Innovativeness: A Split-Population Tobit (SPOT) Duration Model of Timing and Volume of First and Repeat Purchase," Journal of Marketing Research, 32 (4), 444-456.

Chen, Yubo, Shankar Ganesan, and Yong Liu (2009), "Does a Firm's Product Recall Strategy Affect its Financial Value? An Examination of Strategic Alternatives during Product-harm Crises," Journal of Marketing, 73 (6), 214-226.

Chevalier, Judith A. and Dina Mayzlin (2006), "The Effect of Word of Mouth on Sales: Online Book Reviews," Journal of Marketing Research, 43 (3), 345-354.

Cleeren, Kathleen, Marnik G. Dekimpe, and Kristiaan Helsen (2008), "Weathering Product-Harm Crises," Journal of the Academy of Marketing Science, 36 (2), 262-270.

Dawar, Niraj (1998), "Product-Harm Crises and the Signaling Ability of Brands," International Studies of Management and Organization, 28 (3), 109-119.

Dawar, Niraj and Madan N. Pillutla (2000), "Impact of Product-Harm Crises on Brand Equity: The Moderating Role of Consumer Expectations," Journal of Marketing Research, 37 (2), 215-226.

De Alessi, Louis and Robert J. Staaf (1994), "What Does Reputation Really Assure? The Relationship of Trademarks to Expectations and Legal Remedies," Economic Inquiry, 32 (3), 477-485.

Dhar, Sanjay. K. and Stephen J. Hoch (1997), "Why Store Brand Penetration Varies by Retailer," Marketing Science, 16 (3), 208-227.

Dutta, Sujay and Chris Pullig (2011), "Effectiveness of Corporate Responses to Brand Crises: The Role of Crisis Type and Response Strategies," Journal of Business Research, 64 (12), 1281-1287.

Eagly. Alice H., Wendy Wood, and Shelly Chaiken (1978), "Causal Inferences about Communicators and their Effect on Opinion Change, ” Journal of Personality and Social Psychology, 178, 36 (4), 424435.

Ebbes, Peter, Dominik Papies and Harald J. van Heerde (2011), “The Sense and Non-sense of Holdout Sample Validation in the Presence of Endogeneity," Marketing Science, 30 (6), 1115-1122.

Erdem, Tülin and Joffre Swait (1998), "Brand Equity as a Signaling Phenomenon," Journal of Consumer Psychology, 7 (2), 131-157.

Erdem, Tülin, Joffre Swait and Jordan Louviere (2002), "The Impact of Brand Credibility on Consumer Price Sensitivity," International Journal of Research in Marketing, 19 (1), 1-19.

Folkes, Valerie S. (1984), "Consumer Reactions to Product Failure: An Attributional Approach," Journal of Consumer Research, 10 (4), 398-409.

Folkes, Valerie S. (1988), "Recent Attribution Research in Consumer Behavior: A Review and New Directions," Journal of Consumer Research, 14 (4), 548-560.

Gielens, Katrijn and Jan-Benedict E.M. Steenkamp (2007), "Drivers of Consumer Acceptance of New Packaged Goods: An Investigation across Products and Countries," International Journal of Research in Marketing, 24 (June), 97-112.

Gomez-Arias, J. Tomas and Laurentino Bello-Acebron (2008), "Why Do Leading Brand Manufacturers Supply Private Labels?” Journal of Business \& Industrial Marketing, 23 (4), 273-78.

Grégoire, Yany and Robert J. Fisher (2008), "Customer Betrayal and Retaliation: When Your Best Customers Become Your Worst Enemies," Journal of the Academy of Marketing Science, 36 (2), 247-261.

Griffin, Mitch, Barry J. Babin, and Jill S. Attaway (1991), “An Empirical Investigation of the Impact of Negative Public Publicity on Consumer Attitudes and Intentions," Advances in Consumer Research, 18 (1), 334-341.

Gürhan-Canli, Zeynep and Anne Fries (2010), "Branding and Corporate Social Responsibility (CSR)," in Brands and Brand Management: Contemporary Research Perspectives, Barbara Loken, Rohini Ahluwalia and Michael J. Houston, Eds., New York, Psychology Press. 
Hair, Joseph F., William C. Black, Barry J. Babin, and Rolph E. Anderson (2010), Multivariate Data Analysis: A Global Perspective (7th edition), Upper Saddle River, Pearson Prentice Hall.

Herr, Paul M., Frank R. Kardes and John Kim (1991), "Effects of Word-of-Mouth and Product-Attribute Information on Persuasion: An Accessibility-Diagnosticity Perspective," Journal of Consumer Research, 17 (4), 454-462.

Hoeffler, Steve and Kevin L. Keller (2003), “The Marketing Advantages of Strong Brands,” Brand Management, 10 (6), 421-445.

Judge, George G., R. Carter Hill, William E. Griffiths, Helmut Lutkepohl and Tsoung-Chao Lee (1998), Introduction to the Theory and Practice of Econometrics (2nd Edition), Hoboken, John Wiley \& Sons.

Keller, Kevin L. (1993), "Conceptualizing, Measuring and Managing Customer-Based Brand Equity," Journal of Marketing, 57 (1), 1-22.

Kim, Peter H., Kurt T. Dirks, Cecily D. Cooper and Donald L. Ferrin (2006), "When More Blame is Better than Less: The Implications of Internal vs. External Attributions for the Repair of Trust After a Competence-vs. Integrity-Based Trust Violation," Organizational Behavior and Human Decision Processes, 99 (1), 49-65.

Klein, Jill and Niraj Dawar (2004), "Corporate Social Responsibility and Consumers' Attributions and Brand Evaluations in a Product-Harm Crisis," International Journal of Research in Marketing, 21 (3), 203-217.

Kumar, Nirmalya and Jan-Benedict E.M. Steenkamp (2007), Private Label Strategy: How to Meet the Store Brand Challenge, Boston, Harvard Business School Press.

Lamey, Lien, Barbara Deleersnyder, Marnik G. Dekimpe and Jan-benedict E.M. Steenkamp (2007), "How Business Cycles Contribute to Private-Label Success: Evidence from the U.S. and Europe," Journal of Marketing, 71 (1), 1-15.

Leclerc, France, Christopher K. Hsee, and Joseph C. Nunes (2005), "Narrow Focusing: Why The Relative Position of a Good In Its Category Matters More Than It Should," Marketing Science, 24 (2), 194205.

Leeflang, Peter S.H. and Dick R. Wittink (1996), "Competitive Reaction Versus Consumer Response: Do Managers Overreact?” International Journal of Research in Marketing, 13 (2), 103-119.

Leeflang, Peter S.H., Dick Wittink, Michel Wedel, and Philippe A. Naert (2000), Building Models for Marketing Decisions. Boston, Kluwer Academic Publishers.

Leenheer, Jorna, Harald J. van Heerde, Tammo H.A. Bijmolt, and Ale Smidts (2007), "Do Loyalty Programs Really Enhance Behavioral Loyalty? An Empirical Analysis Accounting for SelfSelecting Members," International Journal of Research in Marketing, 21 (1), 31-47.

Lei, Jing, Niraj Dawar, and Jos Lemmink (2008), "The Impact of Brand Relatedness on Negative Spillover Effects in Brand Portfolios," Journal of Marketing, 72 (3), 111-123.

Lei, Jing, Niraj Dawar and Zeynep Gürhan-Canli (2012), "Base-Rate Information in Consumer Attributions of Product-Harm Crises," Journal of Marketing Research, 49 (3), 336-348.

Lesaffre Emmanuel, Dimitris Rizopulos, and Roula Tsonaka (2007), "The Logistic Transform for Bounded Outcome Scores," Biostatistics, 8 (1), 72-85.

Lin, Danyu (1994), "Cox Regression Analysis of Multivariate Failure Time Data: the Marginal Approach," Statistics in Medicine, 13 (21), 2233-2247.

Liu, Yan and Venkatesh Shankar (2012), "The Dynamic Impact of Product-Harm Crises on Brand Equity and Advertising Effectiveness: An Empirical Analysis of the Automobile Industry." SSRN Working Paper.

Liu, Yong, Yubio Chen, Shankar Ganesan and Ronald Hess (2012), "Product-harm Crisis Management and Firm Value," in Handbook of Marketing and Finance, Shankar Ganesan, Ed.. Cheltenham, Edward Elgar Publishing Ltd. 
Luan, Jackie and K. Sudhir (2010), "Forecasting Marketing Mix Responsiveness for New Products, Journal of Marketing Research, 47 (3), 444-457.

Ma, Yu, Kusum L. Ailawadi, Dinesh K. Gauri and Dhruv Grewal (2011), "An Empirical Investigation of the Impact of Gasoline prices on Grocery Shopping Behavior," Journal of Marketing, 75 (2), 18-35.

MacInnis, Deborah J. (2011), "A Framework for Conceptual Contributions in Marketing," Journal of Marketing, 75 (4), 136-154.

MacKinsey, Scott B. and Richard. J. Lutz. (1989), “An Empirical Examination of the Structural Antecedents of Attitude Toward the Ad in An Advertising Pretesting Context?," Journal of Marketing, 53 (2), 48-65.

Maheswaran, Durairaj and Shelly Chaiken (1991), 'Promoting Systematic Processing in Low-Motivation Settings: Effect of Incongruent Information on Processing and Judgment," Journal of Personality and Social Psychology, 61 (1), 13-25.

Marn, Mike V., Erik V. Roegner, and Craig C. Zawada (2003), "The Power of Pricing”, McKinsey Quarterly, 1, 26-40.

Mizik, Nathalie and Robert Jacobson (2009), "Financial Markets Research in Marketing," Journal of Marketing Research, 46 (3), 320-324.

Moore, Danny L. and J.Wesley Hutchinson (1985), "The Influence of Affective Reactions to Advertising: Direct and Indirect Mechanisms of Attitude Change," in Psychological Processes and Advertising Effects: Theory, Research, and Application, Linda F. Alwitt and Andrew A. Mitchell, eds. Hillsdale, Lawrence Erlbaum.

Moorman, Christine, Simone Wies, Natalie Mizik and Fredrika J. Spencer (2012), "Firm Innovation and the Ratchet Effect Among Consumer Packaged Goods Firms," Marketing Science, Forthcoming.

Nijs, Vincent, Marnik G. Dekimpe, Jan-Benedict E.M. Steenkamp, and Dominique M. Hanssens (2001), "The Category Demand Effects of Price Promotions," Marketing Science, 20 (1), 1-22.

Nooteboom, Bart, Hans Berger, and Niels G. Noorderhaven (1997), "Effect of Trust and Governance on Relational Risk," Academy of Management Journal, 40 (2), 308-338.

Pauwels, Koen and Dominique M. Hanssens (2007), "Performance Regimes and Marketing Policy Shifts," Marketing Science, 26 (3), 293-311.

PWC (2006), Price Waterhouse Coopers, [http://www.pwcglobal.com/cz/eng/about/pressrm/2006/pressrm09_06.html].

Ramaswamy, Venkatraman, Hubert Gatignon, and David J. Reibstein (1994), "Competitive Marketing Behavior in Industrial Markets," Journal of Marketing, 58 (2), 45-55.

Riordan, Catherine A., Nancy A. Marlin, and Roland T. Kellogg (1983), "The Effectiveness of Accounts Following Transgressions," Social Psychology Quarterly, 46 (3), 213-219.

Roehm, Michelle L. and Alice M. Tybout (2006), "When Will a Brand Scandal Spill Over, and How Should Competitors Respond?" Journal of Marketing Research, 43 (3), 366-373.

Rotemberg, Julio J. and Garth Saloner (1986), "The Supergame-Theoretic Model of Price Wars During Booms," American Economic Review, 76 (3), 390-407.

Rubel, Olivier, Prasad A. Naik and Shuba Srinivasan (2011), "Optimal Advertising when Envisioning a Product-Harm Crisis," Marketing Science, 30 (6), 1048-1065.

Schultz, Randolph L. and Dick R. Wittink (1976), "The Measurement of Industry Advertising Effects," Journal of Marketing Research, 13 (1), 71-75.

Shaver J. Myles (2005), "Testing for Mediating Variables in Management Research: Concerns, Implications and Alternative Strategies," Journal of Management, 31 (3), 330-353.

Siomkos, George, Amalia Triantafillidou, Aikaterini Vassilikopoulou and Iannnis Tsiamis (2010), "Opportunities and Threats for Competitors in Product-harm Crises," Marketing Intelligence \& Planning, 28 (6), 770-791. 
Skurnik, Ian, Carolyn Yoon, Denise C. Park, and Norbert Schwarz (2005), "How Warnings about False Claims Become Recommendations,” Journal of Consumer Research, 31 (4), 713-724.

Srinivasan, Shuba, Koen Pauwels and Vincent Nijs (2008), "Demand-Based Pricing versus Past-Price Dependence: A Cost-Benefit Analysis," Journal of Marketing, 72 (2), 15-27.

Steenkamp, Jan-Benedict E.M., Vincent R. Nijs, Dominique M. Hanssens and Marnik G. Dekimpe (2005), "Competitive Reactions to Advertising and Promotion Attacks," Marketing Science, 24 (1), $35-54$.

Steenkamp, Jan-Benedict E.M., Harald J. van Heerde, and Inge Geyskens (2010), "What Makes Consumers Willing to Pay a Price Premium for National Brands over Private Labels?" Journal of Marketing Research, 47 (6), 255-267.

Szymanowski, Maciej and Els Gijsbrechts (2012), "Consumption-Based Cross-Brand Learning: Are Private Labels Really Private?”, Journal of Marketing Research, 49 (2), 231-246.

Thirumalai, Sriram and Kingshuk K. Sinha (2011), "Product Recalls in the Medical Device Industry: An Empirical Exploration of the Sources and Financial Consequences." Management Science, 57 (2), 376-392.

Valdes-Dapena, Peter (2010), “GM Offers \$1,000 Incentive to Toyota Owners,” CNN Money, January 27 [http://money.cnn.com/2010/01/27/autos/gm_toyota_incentives/index.htm].

Van Heerde, Harald J., Kristiaan Helsen and Marnik G. Dekimpe (2007), "The Impact of a Product-Harm Crisis on Marketing Effectiveness," Marketing Science, 26 (2), 230-245.

Villas-Boas, J. Miguel and Russell S. Winer (1999), "Endogeneity in Brand Choice Models," Management Science, 45 (10), 1324-1338.

Wang, Alex (2006), "When Synergy in Marketing Communication Online Enhances Audience Response: The Effects of Varying Advertising and Product Publicity Messages," Journal of Advertising Research, 46 (2), 160-170.

Whetten, David A. (1989). "What Constitutes a Theoretical Contribution?" The Academy of Management Review, 14 (4): 490-495.

Wooldridge, Jeffrey M. (2002), Econometric Analysis of Cross Section and Panel Data, Cambridge, MIT Press.

Yadav, Manjit S. (2010), “The Decline of Conceptual Articles and Implications for Knowledge Development," Journal of Marketing, 74 (1), 1-19.

Zenor, Michael J., Bart J. Bronnenberg and Leigh McAlister (1998), "The Impact of Marketing Policy on Promotional Price Elasticities and Baseline Sales," Journal of Retailing and Consumer Services, 5 (1), 25-32.

Zhao, Yi, Ying Zhao, and Kristiaan Helsen (2011), "Consumer Learning in a Turbulent Market Environment: Modeling Consumer Choice Dynamics in the Wake of a Product-Harm Crisis," Journal of Marketing Research, 48 (2), 255-267. 


\section{Endnotes}

${ }^{1}$ A recent exception is Liu and Shankar (2012) that studies advertising effectiveness, and the moderating impact of the severity of the crisis, for different recalls in the automobile industry.

${ }^{2}$ Given our main interest in the contingency effects, we develop formal hypotheses for the various interaction effects. For the main effects, we briefly review prior evidence on their impact, and include them in our empirical testing. However, no formal hypotheses are developed for the main effects.

${ }^{3}$ To account for the bounded range of this variable, we use a logit-type transformation, as explained in the Data Section.

${ }^{4}$ To make the measure comparable across categories, we divide the change in category purchases by the average of the pre- and post-crisis purchases. To overcome the bounded range of this variable, we again use a logit-type transformation, as explained in the Data Section.

${ }^{5}$ For the UK, we looked at the archives of the Food Standards Agency and the Trading Standards Institute. For the Dutch recall cases, we consulted the archives of the Voedsel Waren Autoriteit ("Food Products Authority") and the Consumentenbond ("Consumer Reports").

${ }^{6}$ We limit our media search to newspapers with a circulation of at least $1 \%$ of the population. This includes for the UK both the weekly and Sunday editions of (in alphabetical order) the Daily Express, the Daily Mail, the Daily Mirror, the Daily Star, the Daily Telegraph, the Independent, News of the World, the People, the Sun, and the Times, for a total of 17 newspapers. For the Netherlands, we include Algemeen Dagblad, de Telegraaf, NRC Handelsblad and De Volkskrant. Free newspapers are not part of the electronic databases, and could thus not be included in the media search.

${ }^{7} \Delta C P_{i j}$, as specified in equation (3), is constrained to the interval [-2,2]. To account for the bounded nature of this measure, we apply the logit-type transformation described in Lesaffre, Rizopulos, and Tsonaka (2007) for a response $\mathrm{U}$ that is limited to the interval (a,b): $Z=\ln \left(\frac{U-a}{b-U}\right)$. Given that $\Delta C P_{i j}$ is limited to the interval [-2,2], we add a small amount to $\mathrm{a}$ and $\mathrm{b}$ to avoid that the expression takes the log of zero (cfr., Bass et al. 2009). The transformation results in the following dependent variable: ${ }_{\Delta C P_{i j}^{*}} \equiv \ln \left(\frac{\Delta C P_{i j}+2.01}{2.01-\Delta C P_{i j}}\right)$.

${ }^{8}$ Because brand share is a ratio, this measure is already comparable across categories. Since this variable is constrained to [-1,1], we again apply the logit-type transformation described in Lesaffre et al. (2007):

$\Delta B S_{i j}^{*} \equiv \ln \left(\frac{\Delta B S_{i j}+1.01}{1.01-\Delta B S_{i j}}\right)$. Note that this measure becomes zero if the household never switches brands.

${ }^{9}$ The largest non-affected competitors are identified on the basis of the total volume sold during the year before the crisis.

${ }^{10}$ For the sake of readability, we focus on the effects of the exogenous variables on the change in relative brand/category advertising and price. We do not report the effects of the instrumental variables (IVs), because (i) their substantive managerial relevance is much lower, and because of (ii) their large number. For example, for the endogenous variable category advertising in the category-purchases model, we include main effects for eight IVs and $2 * 8=16$ interaction effects, for a total of 24 effects involving IVs for this one endogenous variable alone. Across all endogenous variables in both the brand-share and category-purchase model, there are 192 main and interaction effects involving IVs. The full set of first-stage regression results is available on request from the first author.

${ }^{11}$ We thus estimate four (rather than 2 ) endogenous variables per model, and also adapt the IVs accordingly. As such, for brand share we use the change between period $t^{*}-1$ and $t^{*}-2$ in both own brand advertising (price) and the 
advertising (price) of the five largest non-affected competitors, rather than a single change in relative brand advertising (price) during the same period. For category purchases, the included IVs are the change between period $t^{*}-1$ and $t^{*}-2$ in both the advertising (price) of the affected brands and the combined advertising (price) of the five largest non-affected competitors, rather than the single sum across affected and non-affected brands.

${ }^{12}$ Detailed results for all robustness checks are available on request from the first author.

${ }^{13}$ In a follow-up analysis, we regressed the change in competition density $(\mathrm{C} 4)$ on various crisis characteristics. We found that the market becomes more concentrated when the crisis affects a stronger brand. In addition, Dutch categories become less concentrated after a crisis than UK categories. Given our limited sample of affected categories $(N=40)$, we were not able to explore this further. 
TABLE 1: OPERATIONALIZATIONS AND DATA SOURCES OF INSTRUMENTAL VARIABLES

\begin{tabular}{|c|c|c|}
\hline $\begin{array}{l}\text { Instrumental } \\
\text { Variable }\end{array}$ & Operationalization & Data source \\
\hline $\begin{array}{l}\text { Lagged advertising } \\
\text { change }\end{array}$ & $\begin{array}{l}\text { Change in relative brand advertising/total } \\
\text { category advertising between one and } \\
\text { two years before the crisis }\end{array}$ & AC Nielsen advertising data \\
\hline $\begin{array}{l}\text { Lagged price } \\
\text { change }\end{array}$ & $\begin{array}{l}\text { Change in relative brand price/total } \\
\text { category price between one and two years } \\
\text { before the crisis }\end{array}$ & $\begin{array}{l}\text { TNS UK/ GfK Netherlands } \\
\text { household-panel data }\end{array}$ \\
\hline $\begin{array}{l}\text { Lagged brand } \\
\text { share/category sales }\end{array}$ & $\begin{array}{l}\text { Change in brand share of the affected } \\
\text { brands/category purchases between one } \\
\text { and two years before the crisis (based on } \\
\text { the full panel) }\end{array}$ & $\begin{array}{l}\text { TNS UK/ GfK Netherlands } \\
\text { household-panel data }\end{array}$ \\
\hline Change in CPI & $\begin{array}{l}\text { Change in country-specific Consumer } \\
\text { Price Index between the year of the crisis } \\
\text { and one year before }\end{array}$ & OECD statistics \\
\hline $\begin{array}{l}\text { Change in fuel } \\
\text { prices }\end{array}$ & $\begin{array}{l}\text { Change in country-specific fuel prices } \\
\text { between the year of the crisis and one } \\
\text { year before }\end{array}$ & International Labor Organization \\
\hline $\begin{array}{l}\text { Change in rental } \\
\text { prices }\end{array}$ & $\begin{array}{l}\text { Change in country-specific rental prices } \\
\text { between one year and two years before } \\
\text { the crisis }\end{array}$ & International Labor Organization \\
\hline $\begin{array}{l}\text { Change in labor } \\
\text { costs }\end{array}$ & $\begin{array}{l}\text { Change in country-specific unit labor } \\
\text { costs between the year of the crisis and } \\
\text { one year before }\end{array}$ & OECD statistics \\
\hline Category dummy & $\begin{array}{l}\text { Dummy variable that indicates whether } \\
\text { or not the category is a beverage }\end{array}$ & $\begin{array}{l}\text { TNS UK/ GfK Netherlands } \\
\text { household-panel data }\end{array}$ \\
\hline
\end{tabular}


TABLE 2: VARIABLE DEFINITIONS AND SUMMARY STATISTICS ${ }^{(a)}$

\begin{tabular}{llrr}
\hline & Description & Mean & St. Dev. \\
\hline $\begin{array}{l}\text { Dependent variables } \\
\begin{array}{l}\text { Change in brand share } \\
(N=44,743)\end{array}\end{array}$ & $\begin{array}{l}\text { Difference in the post-crisis (one year) and pre-crisis (one year) volume } \\
\text { share of the affected brand (equation (4)) }\end{array}$ & -0.34 & 0.34 \\
$\begin{array}{l}\text { Change in category purchases } \\
(N=411,266)\end{array}$ & $\begin{array}{l}\text { Difference in the post-crisis (one year) and pre-crisis (one year) } \\
\text { category-purchase volume of the household (equation (3)). }\end{array}$ & 0.26 & 1.38 \\
\hline
\end{tabular}

Independent variables
Crisis characteristics $(N=60)$
Publicity
Blame $^{(b)}$

Fraction of newspapers that reported on the crisis during a time span of

$0.23 \quad 0.34$ three months before and one year after the recall announcement. Dummy for whether the company acknowledged the blame for the crisis $20 \% \quad 40 \%$ either in the recall announcement or in the surrounding publicity.

\section{Marketing variables}

Change in relative brand advertising Difference in the post- and pre-crisis share of voice, expressed relative $(N=60)$

to the expenditures of the five largest non-affected competitors and the

$-0.03 \quad 0.12$ brand itself.

Change in relative brand price $(N=60)$

Difference in the post- and pre-crisis average (per volume unit) brand price, relative to the weighted average price of the five main

Change in category advertising $(N=40)$ competitors.

Difference in the post- and pre-crisis total advertising expenditures of all affected brands and the five largest non-affected competitors, normalized by the average of their total advertising expenditures before and after.

Change in category price $(N=40) \quad$ Difference in average category price (per volume unit) of all affected brands and the five largest non-affected competitors, normalized by their $0.01 \quad 0.05$ average price before and after.

\section{Control variables}

Brand loyalty $(N=44,743)$

Category usage $(N=411,266)$

Price premium: ${ }^{(c)}$

Brand-share model $(N=40)$

Category-purchase model $(N=60)$

Number of affected brands $(N=60)$

Private-label dummy ${ }^{(b)}(N=60)$

Competition density $(N=60)$

Country dummy ${ }^{(b)}(N=60)$
Pre-crisis within-household market share (in volume).

$0.39 \quad 0.35$

Pre-crisis total volume purchased by the household in the category, normalized by category average across households.

Difference in the pre-crisis (weighted) average price of the affected brand(s) and the cheapest private label in the category, normalized by the pre-crisis (weighted) average price of the affected brand(s).

$1.00 \quad 1.55$

0.46

0.30

$0.42 \quad 0.30$

$5.17 \quad 6.14$

Number of brands that were recalled in the crisis.

$72 \% \quad 45 \%$

Dummy for Private Label $(=1)$ or National Brand $(=0)$.

$0.73 \quad 0.15$

Sum of market shares of the largest four players in the market.

$40 \%$

(a) We report the statistics for the dependent variables before the logistic transformation, and for the independent variables before mean-centering. The sample size for the brand-level variables is lower than the sample size of the category variables, because there are fewer households buying a certain brand than households buying in the category. At the brand level, there are 60 unique cases; at the category level, there are 40 unique case s.

(b) Dummy variables. We report the percentage of observations having the value of 1 .

(c) The price premium for the brand-share model (versus the category-purchase model) is based on the difference in average price between the brand under inspection (versus all affected brands in the category) and the cheapest private label in the category. Therefore, we obtain slightly different summary statistics. 
TABLE 3: CORRELATION MATRIX ${ }^{(a)}$

\begin{tabular}{|c|c|c|c|c|c|c|c|c|}
\hline & Publicity & Blame & $\begin{array}{c}\text { Price } \\
\text { Premium } \\
\end{array}$ & $\begin{array}{c}\text { Number of } \\
\text { affected } \\
\text { brands }\end{array}$ & $\begin{array}{c}\text { Private } \\
\text { label } \\
\text { dummy } \\
\end{array}$ & Advertising & Price & $\begin{array}{c}\text { Competition } \\
\text { density }\end{array}$ \\
\hline \multicolumn{9}{|l|}{ Publicity } \\
\hline Blame & 0.17 & & & & & & & \\
\hline \multicolumn{2}{|c|}{ Price Premium -0.03 } & $-0.34 * * *$ & & & & & & \\
\hline $\begin{array}{l}\text { Number of } \\
\text { affected } \\
\text { brands }\end{array}$ & 0.08 & $-0.32 * *$ & $0.28 * *$ & & & & & \\
\hline $\begin{array}{l}\text { Private label } \\
\text { dummy }\end{array}$ & -0.12 & $-0.61 * * *$ & $0.38 * * *$ & $0.27 * *$ & & & & \\
\hline Advertising & -0.09 & -0.07 & -0.14 & 0.16 & 0.11 & & & \\
\hline Price & -0.10 & 0.07 & $-0.36 * * *$ & $-0.37 * * *$ & -0.17 & -0.05 & & \\
\hline $\begin{array}{l}\text { Competition } \\
\text { density }\end{array}$ & $0.27 * *$ & 0.14 & $-0.53 * * *$ & $-0.33 * *$ & $-0.22 *$ & 0.10 & 0.17 & \\
\hline $\begin{array}{l}\text { Country } \\
(\mathrm{NL}=1)\end{array}$ & $0.62 * * *$ & 0.02 & 0.11 & $0.55 * * *$ & -0.02 & 0.06 & $-0.29 * *$ & 0.13 \\
\hline
\end{tabular}

(a) The matrix shows the correlations between the crisis characteristics $(N=60) . * * *$ and $* * *$ indicate correlations significant at, respectively, $10 \%, 5 \%$ and $1 \%$ significance level. 
TABLE 4: EMPIRICAL RESULTS FOR THE BRAND-SHARE MODEL ${ }^{(a)}$

\begin{tabular}{lc}
\hline Intercept & -0.112 \\
& $(0.098)$ \\
\hline Crisis characteristics & \\
Negative Publicity & 0.001 \\
& $(0.056)$ \\
Blame & 0.079 \\
& $(0.111)$ \\
\hline Marketing variables & \\
$\Delta$ Relative brand advertising & $0.535^{* * *}$ \\
& $(0.190)$ \\
$\Delta$ Relative brand price & 0.292 \\
& $(0.292)$ \\
\hline
\end{tabular}

\section{Interaction effects}

$\Delta$ Relative brand advertisin $g \times$ Negative Publicity

$1.221 *$

$(0.661)$

$\Delta$ Relative brand price $\times$ Negative Publicity

0.006

$(0.878)$

$\Delta$ Relative brand advertisin $\mathrm{g} \times$ Blame

$-0.456 * *$

H1 (+): supported

$(0.200)$

$\Delta$ Relative brand price $\times$ Blame

$-0.962 *$

(0.574)

\section{Control variables}

Brand loyalty

$-1.838 * * *$

$(0.072)$

Price premium of affected brand

$-0.138$

$(0.162)$

Number of affected brands

$-0.002$

$(0.005)$

Private-label dummy (1 for PL, 0 for NB)

$0.141^{*}$

$(0.084)$

Competition density

$-0.257 * *$

$(0.129)$

Country Dummy $(\mathrm{NL}=1)$

$-0.025$

$(0.067)$

Number of observations

44,743

R-squared

0.277

(a) Robust standard errors between parentheses. ${ }^{*}, * * * * *$ indicate a significant two-tailed result at, respectively, $10 \%$, $5 \%$ and $1 \%$ significance level. 
TABLE 5: EMPIRICAL RESULTS FOR THE CATEGORY-PURCHASE MODEL ${ }^{(a)}$

\begin{tabular}{|c|c|c|}
\hline Intercept & $\begin{array}{l}-0.315 \\
(0.194)\end{array}$ & Hypotheses \\
\hline \multicolumn{3}{|l|}{ Crisis characteristics } \\
\hline Negative Publicity & $\begin{array}{c}0.423 \\
(0.290)\end{array}$ & \\
\hline Blame & $\begin{array}{l}1.173 * * * \\
(0.267)\end{array}$ & \\
\hline \multicolumn{3}{|l|}{ Marketing variables } \\
\hline$\Delta$ Category advertising & $\begin{array}{l}0.813 * * * \\
(0.238)\end{array}$ & \\
\hline$\Delta$ Category price & $\begin{array}{l}-5.827 * \\
(3.580) \\
\end{array}$ & \\
\hline \multicolumn{3}{|l|}{ Interaction effects } \\
\hline$\Delta$ Category advertisin $g \times$ Negative Publicity & $\begin{array}{r}3.373^{*} \\
(1.865)\end{array}$ & $\mathrm{H} 2(+)$ : supported \\
\hline$\Delta$ Category price $\times$ Negative Publicity & $\begin{array}{l}-13.154 * * \\
(6.128)\end{array}$ & H4 (-): supported \\
\hline$\Delta$ Category advertisin $g \times$ Blame & $\begin{array}{l}-2.053 * * * \\
(0.537)\end{array}$ & H6 (-): supported \\
\hline$\Delta$ Category price $\times$ Blame & $\begin{array}{r}5.158 \\
(4.478) \\
\end{array}$ & H8 (-): not supported \\
\hline $\begin{array}{l}\text { Control variables } \\
\text { Category Usage }\end{array}$ & $\begin{array}{l}-0.728 * * * \\
(0.035)\end{array}$ & \\
\hline Price premium of affected brands & $\begin{array}{l}-0.081 \\
(0.334)\end{array}$ & \\
\hline Number of affected brands & $\begin{array}{c}0.025 \\
(0.018)\end{array}$ & \\
\hline Private-label dummy ( 1 for PL, 0 for NB) & $\begin{array}{l}1.125^{* * *} \\
(0.184)\end{array}$ & \\
\hline Competition density & $\begin{array}{l}-0.686 \\
(0.639)\end{array}$ & \\
\hline Country Dummy (NL=1) & $\begin{array}{l}-0.506^{* *} \\
(0.223)\end{array}$ & \\
\hline Number of observations & 411,266 & \\
\hline R-squared & 0.138 & \\
\hline
\end{tabular}

(a) Robust standard errors between parentheses. *,**,*** indicate a significant two-tailed result at, respectively, 10\%, $5 \%$ and $1 \%$ significance level. 
TABLE 6: HOW BRANDS AND CATEGORIES CAN OVERCOME PRODUCT-HARM CRISES

\begin{tabular}{|c|c|c|c|c|c|c|}
\hline \multicolumn{3}{|c|}{ Type of product-harm crisis } & \multicolumn{2}{|c|}{ Post-crisis recommendations for the brand } & \multicolumn{2}{|c|}{ Post-crisis recommendations for the category } \\
\hline Case & $\begin{array}{l}\text { Extent of } \\
\text { negative } \\
\text { publicity }\end{array}$ & \begin{tabular}{|l|} 
Blame had to \\
be \\
acknowledged
\end{tabular} & Advertising & Brand price & Category advertising & Category price \\
\hline 1 (base) & Low & No & $\begin{array}{l}\text { Increase brand advertising: } \\
\text { effective instrument }\end{array}$ & $\begin{array}{l}\text { Keep brand price: spoiled } \\
\text { arms }\end{array}$ & $\begin{array}{l}\text { Increase category } \\
\text { advertising: effective } \\
\text { instrument }\end{array}$ & $\begin{array}{l}\text { Decrease category price: } \\
\text { effective instrument }\end{array}$ \\
\hline 2 & Low & Yes & $\begin{array}{l}\text { Do not increase advertising: } \\
\text { less effective than in base } \\
\text { case }\end{array}$ & $\begin{array}{l}\text { Decrease price: more } \\
\text { effective than in base case }\end{array}$ & $\begin{array}{l}\text { Do not increase } \\
\text { advertising: less effective } \\
\text { than in base case }\end{array}$ & $\begin{array}{l}\text { Decrease price: as } \\
\text { effective as in base case }\end{array}$ \\
\hline 3 & High & No & $\begin{array}{l}\text { Increase advertising even } \\
\text { more: more effective than in } \\
\text { base case }\end{array}$ & Keep price: spoiled arms & $\begin{array}{l}\text { Increase advertising even } \\
\text { more: more effective than } \\
\text { in base case }\end{array}$ & $\begin{array}{l}\text { Decrease price even more: } \\
\text { more effective than in } \\
\text { base case }\end{array}$ \\
\hline 4 & High & Yes & $\begin{array}{l}\text { Increasing advertising might } \\
\text { be attractive, depending on } \\
\text { the net impact of the two } \\
\text { opposing forces on } \\
\text { advertising effectiveness }\end{array}$ & $\begin{array}{l}\text { Decrease price: more } \\
\text { effective than in base case }\end{array}$ & $\begin{array}{l}\text { Increasing advertising } \\
\text { might be attractive, } \\
\text { depending on the net } \\
\text { impact of the two } \\
\text { opposing forces on } \\
\text { advertising effectiveness }\end{array}$ & $\begin{array}{l}\text { Decrease price even more: } \\
\text { more effective than in } \\
\text { base case }\end{array}$ \\
\hline
\end{tabular}


FIGURE 1: CONCEPTUAL FRAMEWORK(a)

BEFORE PRODUCT-HARM CRISIS

AFTER PRODUCT-HARM CRISIS

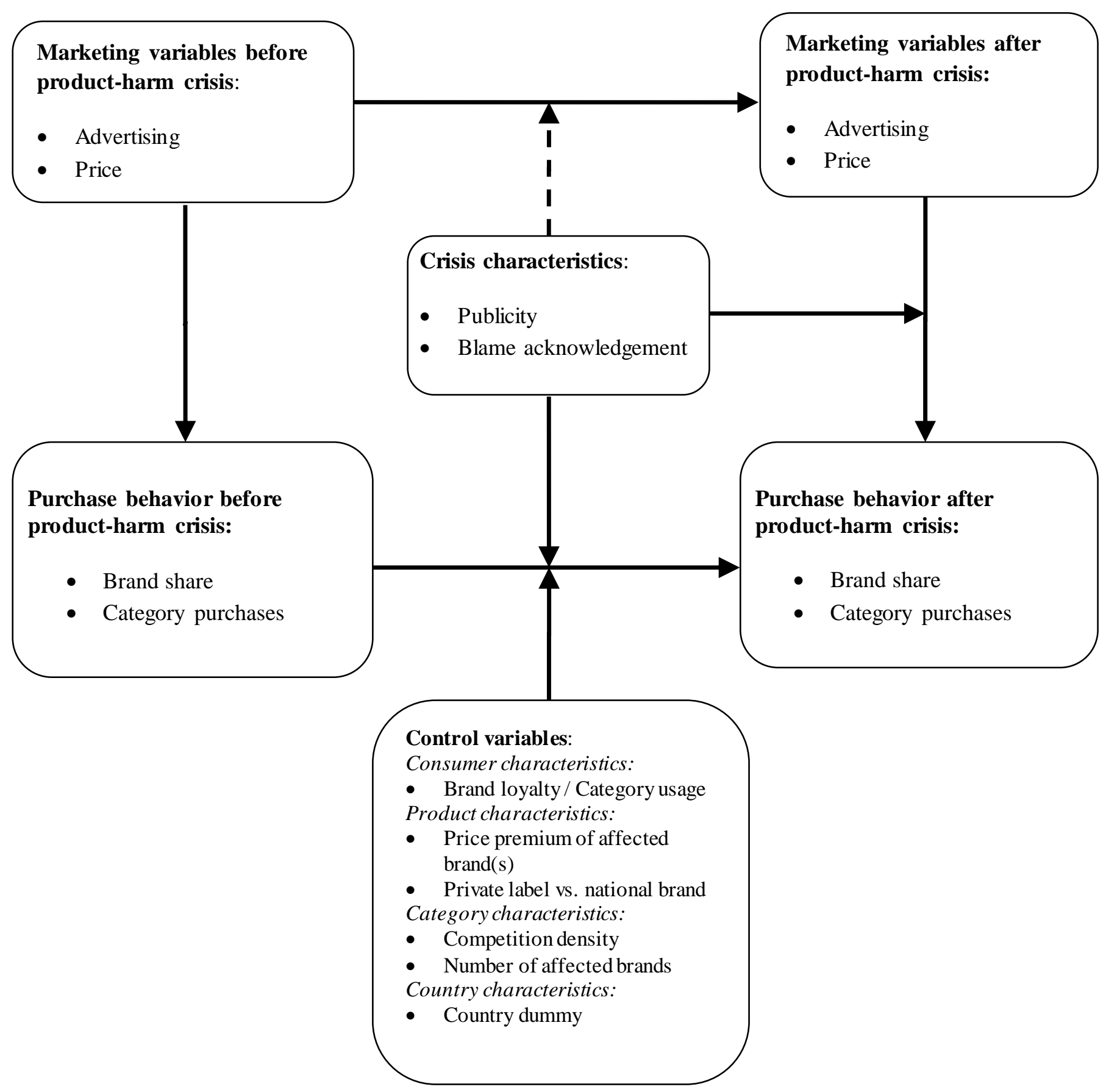

(a) A solid arrow ( $\rightarrow$ indicates an effect that is part of the main model in equations (1) and (2). The dashed arrow $(-\rightarrow)$ indicates the effect of the crisis on the change in marketing variables. Since we use 2 SLS to account for the endogeneity of marketing variables, this effect is part of the first-stage regression of the estimation procedure. 


\section{APPENDIX}

\section{PRODUCT-HARM CRISIS DESCRIPTIONS, LISTED CHRONOLOGICALLY PER COUNTRY. NL = THE NETHERLANDS, UK = UNITED KINGDOM.}

\begin{tabular}{|c|c|c|}
\hline Product-harm crisis & Date & $\begin{array}{r}\text { \# affected brands } \\
\text { (\# brands included } \\
\text { in brand-share } \\
\text { equation) }\end{array}$ \\
\hline $\begin{array}{l}\text { 1. Sauerkraut }(N L) \text { : Albert Heijn had to recall its canned sauerkraut }(520 \mathrm{~g}) \\
\text { because of glass contamination. }\end{array}$ & $01 / 11 / 2000$ & $1(1)$ \\
\hline $\begin{array}{l}\text { 2. Liquor }(N L) \text { : Bacardi-Breezer orange and lemon bottles }(70 \mathrm{cl}) \text { were recalled } \\
\text { because of reported bursts. }\end{array}$ & $10 / 07 / 2003$ & $1(1)$ \\
\hline $\begin{array}{l}\text { 3. Sugar }(N L) \text { : Caribbean Gold had to recall the } 1 \mathrm{~kg} \text { packages and } 500 \mathrm{~g} \text { cubes } \\
\text { packages of cane sugar because of chemical contamination. }\end{array}$ & $07 / 13 / 2004$ & $1(1)$ \\
\hline $\begin{array}{l}\text { 4. Baby food }(N L) \text { : All varieties of Olvarit and Bebirix baby food needed to be } \\
\text { recalled because of glass contamination. }\end{array}$ & $12 / 22 / 2005$ & $2(2)$ \\
\hline $\begin{array}{l}\text { 5. Fruit for babies }(N L) \text { : Olvarit and Bebirix recalled different flavours of their } \\
\text { baby fruit gamma because of glass contamination. }\end{array}$ & $12 / 22 / 2005$ & $2(2)$ \\
\hline $\begin{array}{l}\text { 6. Filet d'Ardenne }(N L) \text { : Filet d'Ardenne of Albert Heijn was recalled due to } \\
\text { incorrect label information. }\end{array}$ & $01 / 06 / 2006$ & $1(1)$ \\
\hline $\begin{array}{l}\text { 7. Yorkham }(N L) \text { : Albert Heijn recalled all packages of Yorkham because of } \\
\text { mislabeling. }\end{array}$ & $01 / 06 / 2006$ & $1(1)$ \\
\hline $\begin{array}{l}\text { 8. Chicken rolled meat }(N L) \text { : All packages of chicken rolled meat were recalled } \\
\text { by Albert Heijn because of label errors. }\end{array}$ & $01 / 06 / 2006$ & $1(1)$ \\
\hline $\begin{array}{l}\text { 9. Minced meat }(N L) \text { : Albert Heijn recalled all packages of AH minced meat } \\
\text { because of wrong label information. }\end{array}$ & $01 / 06 / 2006$ & $1(1)$ \\
\hline $\begin{array}{l}\text { 10. Syrup (NL): } 16 \text { private label brands had to recall different varieties of syrup } \\
\text { because of the detection of particles of glass inside. We observe purchases of } \\
\text { Albert Heijn, Edah, Etos, Kruidvat, Markant, O'Lacy's, Perfekt, Plus, Spar, } \\
\text { Vitafit (Lidl), C1000, Dixap (Covelt), and Super de Boer. } \\
\end{array}$ & $11 / 29 / 2006$ & $16(13)$ \\
\hline $\begin{array}{l}\text { 11. Chicken nuggets (UK): Sainsbury recalled its } 18 \text { fresh nuggets variety }(312 \mathrm{~g}) \\
\text { because of quality defects. }\end{array}$ & $04 / 21 / 2000$ & $1(1)$ \\
\hline $\begin{array}{l}\text { 12. Canned pilchards }(U K) \text { : The Namibian South Atlantic pilchards in tomato } \\
\text { sauce }(425 \mathrm{~g}) \text { of the brands Glenryck and Princes had to be recalled because of } \\
\text { a fault in the manufacture of the can. }\end{array}$ & 2000 & $2(2)$ \\
\hline $\begin{array}{l}\text { 13. Tomato soup }(U K) \text { : } 15 \text { private labels had to recall their cans of tomato soup } \\
\text { (410g) because of too high levels of tin. We only include Morrisons in our } \\
\text { analysis since it was the only brand that had to fully recall this variety. }\end{array}$ & $11 / 16 / 2000$ & $15(1)$ \\
\hline $\begin{array}{l}\text { 14. Butter }(U K) \text { : Kerrygold spreadable butter was recalled because of glass } \\
\text { contamination. }\end{array}$ & $07 / 28 / 2001$ & $1(1)$ \\
\hline $\begin{array}{l}\text { 15. Flavored mineral water }(U K) \text { : Sainsbury recalled its strawberry-flavored } \\
\text { Caledonian still water }(21) \text { because of too low quality. }\end{array}$ & $08 / 10 / 2001$ & $1(1)$ \\
\hline $\begin{array}{l}\text { 16. Custard (UK): Ambrosia Devon had to recall all custard varieties of } 1 \mathrm{~kg} \text { and } \\
500 \mathrm{~g} \text { because of deterioration before use-by-date. }\end{array}$ & $08 / 24 / 2001$ & $1(1)$ \\
\hline $\begin{array}{l}\text { 17. Spring Water }(U K) \text { : Chiltern Hills and Ashridge Spring recalled their bottles } \\
\text { of water after they were found to be contaminated with faeces. Since } \\
\text { Ashridge Spring was not observed in the purchase database, it is not included } \\
\text { in our analysis. }\end{array}$ & $11 / 23 / 2001$ & $2(1)$ \\
\hline $\begin{array}{l}\text { 18. Ice cream }(U K) \text { : Sainsbury dairy-free chocolate iced dessert }(500 \mathrm{ml}) \text { was } \\
\text { recalled because of the detection of traces of milk while labeled milk-free. }\end{array}$ & $12 / 10 / 2001$ & $1(1)$ \\
\hline 19. Profiteroles (UK): Co-op's frozen dairy cream profiteroles (280g) were & $07 / 18 / 2002$ & $1(1)$ \\
\hline
\end{tabular}




\begin{tabular}{|c|c|c|}
\hline recalled because of the detection of traces of nut while labeled nut-free. & & \\
\hline $\begin{array}{l}\text { 20. Baby Food (UK): Heinz recalled different varieties of baby food because they } \\
\text { were incorrectly labeled as milk-free. }\end{array}$ & $08 / 29 / 2002$ & $1(1)$ \\
\hline $\begin{array}{l}\text { 21. Canned soup (UK): Sainsbury had to recall its cream of potato and leek } \\
\text { canned soup }(400 \mathrm{~g}) \text { because of bursting cans and evidence of spoilage. }\end{array}$ & $03 / 14 / 2003$ & $1(1)$ \\
\hline $\begin{array}{l}\text { 22. Liquor (UK): Bacardi Breezer and Coomira Coast recalled all 70cl bottles } \\
\text { because of bursting bottles. We focus on Bacardi Breezer since Coomira } \\
\text { Coast was not observed in the purchase database. }\end{array}$ & $10 / 08 / 2003$ & $2(1)$ \\
\hline $\begin{array}{l}\text { 23. Pesto Sauce (UK): Different brands of pesto sauce were recalled after the } \\
\text { cancer-causing chemical Sudan } 1 \text { was discovered. Only the Bertolli brand is } \\
\text { included in the analysis because Safeway and Sainsbury's only recalled parts } \\
\text { of their varieties and the Al Cirio brand was not observed in the purchase } \\
\text { database. }\end{array}$ & $09 / 16 / 2003$ & $4(1)$ \\
\hline $\begin{array}{l}\text { 24. Muffins (UK): } 6 \text { private labels brands of white muffins had to be recalled } \\
\text { because of mislabeling. Only Asda recalled the whole variety. }\end{array}$ & $10 / 28 / 2004$ & $6(1)$ \\
\hline $\begin{array}{l}\text { 25. Cookies (UK): Sainsbury freefrom coconut and raspberry cookies }(200 \mathrm{~g}) \\
\text { were recalled because of mislabeling. }\end{array}$ & $01 / 28 / 2005$ & $1(1)$ \\
\hline $\begin{array}{l}\text { 26. Ice cream (UK): Sainsbury recalled its frozen freefrom raspberry iced dessert } \\
(500 \mathrm{ml}) \text { because of a wrong label. }\end{array}$ & $04 / 28 / 2005$ & $1(1)$ \\
\hline $\begin{array}{l}\text { 27. Pasta salad (UK): Sainsbury recalled its tuna and sweetcorn pasta salad } \\
\text { (300g) because of inconsistencies between the allergy information on the } \\
\text { package and the ingredient list. }\end{array}$ & $09 / 23 / 2005$ & $1(1)$ \\
\hline $\begin{array}{l}\text { 28. Candy (UK): Basset's milky babies ( } 165 \text { and } 200 \mathrm{~g} \text { ) had to be recalled because } \\
\text { of the presence of pieces of plastic in the candy. }\end{array}$ & $10 / 05 / 2005$ & $1(1)$ \\
\hline $\begin{array}{l}\text { 29. Chocolate (UK): the basic plain chocolate (100g) variety of Sainsbury was } \\
\text { taken off the shelves because of mislabeling. }\end{array}$ & $10 / 06 / 2005$ & $1(1)$ \\
\hline $\begin{array}{l}\text { 30. Toothbrushes }(U K) \text { : Boots smile toothbrushes were recalled because of } \\
\text { choking hazard linked to potential breaks of the product. }\end{array}$ & $10 / 27 / 2005$ & $1(1)$ \\
\hline $\begin{array}{l}\text { 31. Yoghurt (UK): Brooklea (Aldi) thick and creamy strawberry yoghurt }(150 \mathrm{~g}) \\
\text { was recalled because of glass contamination. }\end{array}$ & $02 / 06 / 2006$ & $1(1)$ \\
\hline $\begin{array}{l}\text { 32. Bread slices (UK): Iceland and Morrisons recalled the frozen } 6 \text { cheese \& } \\
\text { garlic slices because of contamination with plastic. We only observe } \\
\text { purchases for the Iceland brand. }\end{array}$ & $02 / 09 / 2006$ & $1(1)$ \\
\hline $\begin{array}{l}\text { 33. Beef paste (UK): Morrisons and Co-op beef paste jars }(75 \mathrm{~g}) \text { were recalled } \\
\text { because of incorrect label information. }\end{array}$ & $03 / 13 / 2006$ & $2(2)$ \\
\hline $\begin{array}{l}\text { 34. Chocolate (UK): Cadbury had to recall different dairy milk chocolate flavors } \\
\text { because of contamination with salmonella. }\end{array}$ & $06 / 23 / 2006$ & $1(1)$ \\
\hline $\begin{array}{l}\text { 35. Pasta sauce (UK): Aldi had to recall its Romano pasta sauce (470g) because } \\
\text { of the detection of particles of glass inside. }\end{array}$ & $08 / 15 / 2006$ & $1(1)$ \\
\hline $\begin{array}{l}\text { 36. Porridge (UK): Asda recalled its simply porridge variety }(500 \mathrm{~g}) \text { because of } \\
\text { the detection of traces of nut while labeled nut-free. }\end{array}$ & $11 / 01 / 2006$ & $1(1)$ \\
\hline $\begin{array}{l}\text { 37. Crisps (UK): Sainsbury's and Co-op had to recall its multi-pack sausage and } \\
\text { tomato flavor crisps ( } 6 \text { times } 25 \mathrm{~g} \text { ) and ready salted crisps multi-pack (6 times } \\
25 \mathrm{~g}) \text {, respectively, because of a label error. }\end{array}$ & $11 / 16 / 2006$ & $2(2)$ \\
\hline $\begin{array}{l}\text { 38. Seafood (UK): The Northern Catch } 15 \text { seafood sticks (250g) of Aldi were } \\
\text { recalled because of a microbiological problem. }\end{array}$ & $11 / 16 / 2006$ & $1(1)$ \\
\hline $\begin{array}{l}\text { 39. Cereals }(U K) \text { : Marks and Spencer had to recall its strawberry and almond } \\
\text { crunch cereals because of mislabeling. }\end{array}$ & $12 / 06 / 2006$ & $1(1)$ \\
\hline $\begin{array}{l}\text { 40. Crackers }(U K) \text { : Prawn crackers }(50 \mathrm{~g}) \text { of six private label brands were } \\
\text { recalled because of incorrect label information. We only observe purchases } \\
\text { for Spar, Asda, Sainsbury's and Tesco. }\end{array}$ & $03 / 19 / 2007$ & $6(4)$ \\
\hline
\end{tabular}

